\title{
Greenhouse gas balance and carbon footprint of beef cattle in three contrasting pasture-management systems in Brazil
}

\author{
Eduardo Barretto de Figueiredo ${ }^{a,}$, Susantha Jayasundara ${ }^{b}$, \\ Ricardo de Oliveira Bordonal a, Telma Teresinha Berchielli ${ }^{a}$, Ricardo Andrade Reis a , \\ Claudia Wagner-Riddle ${ }^{\mathrm{b}}$, Newton La Scala Jr. ${ }^{\mathrm{a}}$ \\ a São Paulo State University - UNESP, College of Agricultural and Veterinarian Sciences, Via de Acesso Prof. Paulo Donato Castellane s/n, 14884-900, \\ Jaboticabal, São Paulo, Brazil \\ b School of Environmental Sciences, University of Guelph, 50 Stone Road East, Guelph, Ontario, N1G 2W1, Canada
}

\section{A R T I C L E I N F O}

\section{Article history:}

Received 29 July 2015

Received in revised form

14 March 2016

Accepted 15 March 2016

Available online 8 April 2016

\section{Keywords:}

Climate change

Land-use change

Livestock emissions

Grazing management

Integrated systems

Meat production

\begin{abstract}
A B S T R A C T
Integrated Systems (IS) have been identified as an efficient land-management strategy for restoring degraded areas worldwide, increasing crops and beef yields and providing technical potential for carbon (C) sequestration in soil and trees as an option for offsetting $\mathrm{CH}_{4}$ and $\mathrm{N}_{2} \mathrm{O}$ emissions from cattle production. The aim of our study is to estimate the greenhouse gas (GHG) balance and the C footprint of beef cattle (fattening cycle) in three contrasting production scenarios on the Brachiaria pasture in Brazil-1) degraded pasture (DP), 2) managed pasture (MP), and 3) the crop-livestock-forest integrated system (CLFIS) - presenting new alternatives of land use as a GHG mitigation strategy. Area-scaled total GHG emissions were highest in MP $\left(84,541 \mathrm{~kg} \mathrm{CO}_{2} \mathrm{eq} \mathrm{ha}{ }^{-1}\right)$, followed by CLFIS $\left(64,519 \mathrm{~kg} \mathrm{CO}_{2} \mathrm{eq} \mathrm{ha}{ }^{-1}\right)$ and DP $\left(8004 \mathrm{~kg} \mathrm{CO}_{2}\right.$ eq ha ${ }^{-1}$ ) over a 10 -yr period. Our results note that the highest $\mathrm{C}$ footprint of beef cattle was in the DP, $18.5 \mathrm{~kg} \mathrm{CO}$ eq per $\mathrm{kg} \mathrm{LW}$ (live weight), followed by $12.6 \mathrm{~kg} \mathrm{CO}$ eq per $\mathrm{kg} \mathrm{LW}$ in the CLFIS and $9.4 \mathrm{~kg} \mathrm{CO}$ eq per $\mathrm{kg} \mathrm{LW}$ in the MP, without taking into account the technical potential for $\mathrm{C}$ sequestration in MP (soil C) and CLFIS (soil and Eucalyptus C). Considering the potential for soil C sequestration in the MP and CLFIS, the $C$ footprint of beef cattle could be reduced to 7.6 and $-28.1 \mathrm{~kg} \mathrm{CO}_{2}$ eq per $\mathrm{kg} \mathrm{LW}$ in the MP and CLFIS, respectively. The conversion of the degraded pasture to a well-managed pasture and the introduction of CLFIS can reduce their associated GHG emissions in terms of $\mathrm{kg} \mathrm{CO}_{2}$ eq emitted per $\mathrm{kg}$ of cattle LW produced, increasing the production of meat, grains and timber. This reduction is primarily due to pasture improvement and increases in cattle yields and the provision of technical potential for $\mathrm{C}$ sinks in soil and biomass to offset cattle-related emissions.
\end{abstract}

๑) 2016 Elsevier Ltd. All rights reserved.

\section{Introduction}

Agriculture, land use and land-use change-related activities contribute close to $25 \%\left(10-12 \mathrm{Pg} \mathrm{CO}_{2} \mathrm{eq} \mathrm{yr}^{-1} ; 1 \mathrm{Pg}=10^{15} \mathrm{~g}\right.$ ) of total global anthropogenic greenhouse gas (GHG) emissions; thus, leveraging the mitigation potential in this sector is extremely important in meeting emission reduction targets (IPCC, 2014). In Brazil, the majority of agricultural land is occupied by pasture $(\sim 159$ million ha), and the rate of land-use intensification has created pressure to convert additional land to grow crops (Barretto et al., 2013), leading to further deforestation and associated GHG

\footnotetext{
* Corresponding author. Tel.: +55 16 32092624; fax: +55 1632024275 .

E-mail address: eduardobfigueiredo@hotmail.com (E.B. de Figueiredo).
}

emissions. On these pastures, Brazil has established the world's largest commercial beef cattle herd (over 212.8 million head in 2011) and has become the world's leading exporter of beef (IBGE, 2013). Within the Brazilian Plan for Mitigation and Adaptation to Climate Change (ABC Plan), one of the main commitments is to recuperate 15 million ha of degraded pasture by 2020 and prevent the degradation of new pastures through correct management. This plan is projected to contribute to the reduction of country's GHG emissions from 36.1\% to 38.9\% by 2020 (Brazil, 2012).

Until recently, beef cattle production in Brazil was considered an enterprise of low investment that relied on extensive grazing systems with minimum external inputs, except mineral supplementation for cattle (Millen and Arrigoni, 2013). Extensive cattle production systems that exploit the natural soil fertility can lead to 
soil and pasture degradation. Pastures incapable of providing forage sufficient for a live weight gain of $50 \mathrm{~kg} \mathrm{ha}^{-1} \mathrm{yr}^{-1}$ are generally regarded as degraded (Macedo, 1995). This decline in pasture productivity implies changes in carbon (C) stocks both above and below ground (Braz et al., 2013). Moreover, degraded pastures are characterized by low soil fertility, compaction, acidity, decreased soil water availability and soil erosion (Cerri et al., 2004). It is estimated that $80 \%$ of the 50 to 60 million ha of grassland in Central Brazil are in some state of degradation (Peron and Evangelista, 2003), and their recovery requires improved soiland pasture-management practices (Marchão et al., 2009).

Previous studies have indicated that no-tillage cropping practices and the recuperation of degraded pasture have both led to increased soil organic carbon (SOC) in different climatic regions in Brazil (Corazza et al., 1999; Silva et al., 2004; La Scala Jr. et al., 2012). Although well-managed pasture can improve soil C status (Corazza et al., 1999; Lilienfein et al., 2003; Maia et al., 2009; Carvalho et al., 2014), degraded pasture can experience soil C depletion (Maia et al., 2009; Carvalho et al., 2010, 2014; Salton et al., 2011). These contrasting results are associated with different soil and forage types and soil-management practices (Maia et al., 2009), reflecting the degree of productivity or degradation of the pasture. The adequate physiological management of the forage and maintenance of soil fertility by liming and optimum fertilization are essential agronomic practices needed to restore degraded pasture (Oliveira et al., 2003), whereas nitrogen is one of the most important nutrients required to achieve this goal (Monteiro et al., 2004).

Recently, integrated systems (IS) have been identified as an efficient land-management strategy for restoring degraded pasture, improving soil $\mathrm{C}$ accumulation and offsetting GHG emissions from beef cattle production (Cerri et al., 2007; Carvalho et al., 2010, 2014; Euclides et al., 2010; IPCC, 2014; Salton et al., 2014). Presenting a comprehensive assessment of IS in Brazil, Gil et al. (2015) described four types of IS: iCL - crop-livestock systems (i.e., integrated production of grains, grasses and animals), iLF - livestock-forestry systems (i.e., integrated production of grasses, animals and trees), iCF crop-forestry systems (i.e., integrated production of grains and trees), and CLFIS - crop-livestock-forestry integration systems (i.e., integrated production of trees, grains, grasses and animals). Furthermore, their report highlighted the potential of IS as a strategy to prevent further deforestation and to optimize land use in Brazil. According to Balbino et al. (2012), the adoption of crop-livestock-forest integration systems (CLFIS) in Brazil has reached 1.6 million ha at present and is expected to grow up to 4 million ha by 2020 . Several published case studies have demonstrated the technical, agronomic and economic feasibility of CLFIS in different regions in Brazil (Dube et al., 2002; Balbino et al., 2012; Pacheco et al., 2012; Salton et al., 2014). However, studies that focus on a comparative analysis of the GHG balance and mitigation potential associated with these alternative beef cattle production systems are scanty.

The aim of our study is therefore to estimate the GHG emission balance and the $C$ footprint of beef cattle production from the fattening cycle in three contrasting production scenarios on the Brachiaria pasture in Brazil-1) a degraded pasture (DP), 2) a managed pasture (MP), and 3) a crop-livestock-forest integration system (CLFIS) - and present new alternatives of land use as a GHG mitigation option. Our hypothesis is that the conversion of a degraded pasture to a well-managed pasture and the introduction of CLFIS may reduce the GHG emission per kilogram of live cattle weight produced in Brazil.

\section{Material and methods}

The calculation of GHG emissions is based on the IPCC (2006) methodology combined with a Brazil-specific database of several scenarios of pasture-management systems. This approach considers inputs and outputs from 1 ha of land within the farm for each scenario. The boundaries of this study consider only the fattening cycle of beef cattle, aiming for more accurate results. In Brazil, specialized farms normally produce calves for the fattening phase. Published research on several case studies of CLFIS in Brazil have shown that a 10-yr period can be the economically optimum time span for one production cycle of Eucalyptus-based CLFIS (Dube et al., 2002; Euclides et al., 2010; Pacheco et al., 2012). Therefore, total GHG emissions and potential sinks over a 10-yr time span were estimated for all three production scenarios. Beef cattle's live weight output per 1 ha of land over a $10-\mathrm{yr}$ time span was estimated for each scenario, and the $\mathrm{C}$ footprint of beef cattle production was estimated in terms of $\mathrm{CO}_{2}$ equivalent $\left(\mathrm{CO}_{2} \mathrm{eq}\right)$ emissions per $1 \mathrm{~kg}$ of live beef-cattle weight produced in three contrasting scenarios. Total GHG emissions were aggregated into $\mathrm{CO}_{2} \mathrm{eq}$ using the 100-yr global warming potential of 1 for $\mathrm{CO}_{2}, 25$ for $\mathrm{CH}_{4}$ and 298 for $\mathrm{N}_{2} \mathrm{O}$ (IPCC, 2007). The GHG emission sources and sinks accounted for the CLFIS (the more complex system) are presented schematically in Fig. 1. In the MP system, emission sources are the same as for the CLFIS depicted in Fig. 1, excluding the emissions associated with crop rotation and tree establishment and sink associated with the tree component, while in the DP (the most

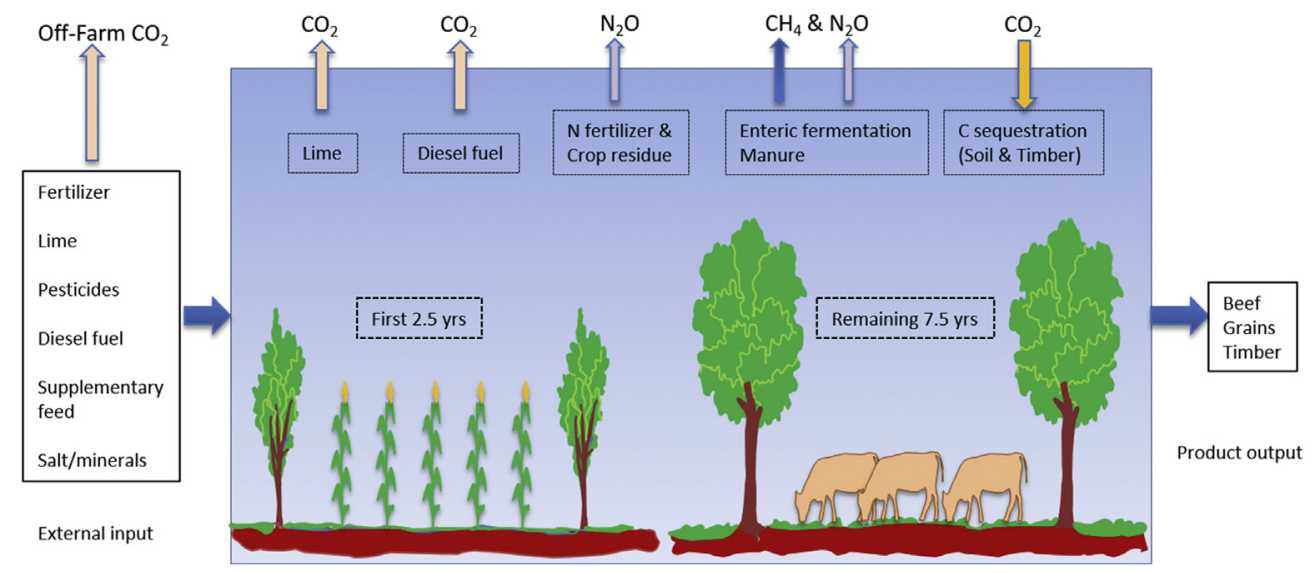

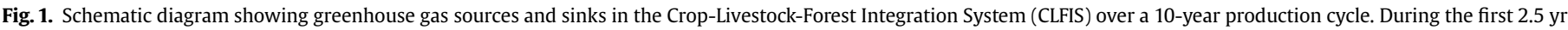

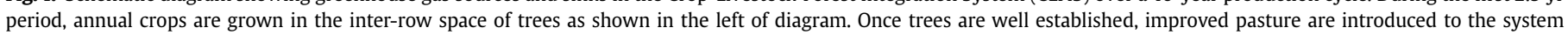
followed by fattening beef cattle for the next $7.5 \mathrm{yr}$ period until trees are ready for harvest as timber (diagram is not to scale). 
simplest system), emission sources considered are $\mathrm{CH}_{4}$ from enteric fermentation and $\mathrm{CH}_{4}$ and $\mathrm{N}_{2} \mathrm{O}$ emissions from manure deposited by grazing cattle. The estimation methodology for each GHG source or sink is explained separately in the following sections.

\subsection{Systems boundaries description}

The degraded pasture (DP) scenario considered in this analysis assumed no external inputs for pasture maintenance and no feed supplementation for cattle (De Oliveira et al., 2001), except mineral salt (Fig. 2a). Therefore, this system, predominantly practiced at present, operates with a low stocking rate, taking a longer time (3 years) to reach the optimum slaughter weight (from 200 to $460 \mathrm{~kg}$ of live weight gain-LW) and producing a low meat yield per unit land area, using Nelore (Bos indicus) steers (Euclides et al., 1998, 2001). Production parameters related to cattle in three pasture systems and those related to crops and Eucalyptus in the CLFIS are presented in Table 1.

In the MP scenario, external inputs such as fertilizer (N, P and K), liming, animal-feed supplements, herbicides and diesel for field operations were assumed to be used annually (Fig. 2b) at the rates presented in Table 2 . These external inputs can lead to higher forage yields and higher cattle-stocking rates (Table 1) and a shorter time (2.0 years) to reach the optimum slaughter weight (from 200 to $450 \mathrm{~kg} \mathrm{LW}$ ) (Ferraz and Felicio, 2010). The average live weight gain assumed here for the MP can be justified on the basis of results from several other studies involving well-managed Brachiaria brizantha pasture combined with feed supplements for cattle that demonstrated a weight gain of $0.673-0.870 \mathrm{~kg}_{\text {animal }}{ }^{-1} \mathrm{day}^{-1}$ during the fattening phase of beef cattle in Brazil (Fernandes et al., 2010; Oliveira et al., 2012).

The CLFIS scenario defined for this analysis was modeled according to previous case studies of Eucalyptus-based CLFIS in Brazil and the productivity of grains, Eucalyptus trees and cattle live weight gain, based on the best performing crop-livestock and tree configuration explained by Pacheco et al. (2012). This system includes an initial period of 2.5 years of grain production under notillage practices without cattle while trees are established. Eucalyptus seedlings are introduced during the rainy season (normally
December and/or January) of the first year. The seedlings are planted in suggested arrangement in rows $14 \mathrm{~m}$ apart with $1.5 \mathrm{~m}$ of space between trees in a row $(14 \times 1.5 \mathrm{~m})$; thus, trees occupy $11 \%$ of the land area at a density of 476 trees ha $^{-1}$ (Pacheco et al., 2012). As trees are being established, three 'summer crops' are sown around October (Pigeon pea - Cajanus cajan L. Millsp.; Soybean - Glycine max L. Merr.; and Maize - Zea mays L.), followed by 3 crops sown in February (e.g., Sorghum - Sorghum bicolor L. or Maize in association with under-seeded Brachiaria spp.), which results in two grain harvests each year (Table 1), except for pigeon pea, which will be crushed and left on the soil surface after flowering. The pasture is established following this initial 2.5-yr cropping period (e.g., total of 6 crops) and remains in the system for the next 7.5 years under intensive management (Figs. 1 and 2c). Cattle are introduced to the pasture at the end of the initial 2.5-yr cropping period for grazing between Eucalyptus tree rows; at this time, the trees are well established (Dube et al., 2002; Pacheco et al., 2012). Studying integrated crop-livestock-forestry systems in Mato Grosso, Brazil, Gil et al. (2015) reported average cattle productivity under these systems to be three times higher than that under conventional farming systems. For the CLFIS scenario, data from Salton et al. (2014) were applied (Table 1), assuming that the same feed supplements were provided to cattle, as described above for the MP system (dry season, 6 months per year).

\section{2. $\mathrm{CH}_{4}$ emissions from enteric fermentation and manure}

For beef cattle grazing on extensive pasture areas in Latin America, IPCC (2006) recommended a default enteric fermentation $\mathrm{CH}_{4}$ emission factor of $56 \mathrm{~kg} \mathrm{CH}$ animal $^{-1} \mathrm{yr}^{-1}$. This default emission factor was applied to cattle grazing in the DP scenario, considering the fact that pasture in this system do not receive any external inputs. Studies conducted over the last several years in Brazil have provided a range of measured values for $\mathrm{CH}_{4}$ produced by enteric fermentation from beef cattle. For example, using the sulfur hexafluoride $\left(\mathrm{SF}_{6}\right)$ technique, Demarchi et al. (2003) reported a mean annual emission rate of $52 \mathrm{~kg} \mathrm{CH}_{4}$ head $^{-1} \mathrm{yr}^{-1}$ for Nellore steers weighing $206-525 \mathrm{~kg}$ head ${ }^{-1}$ grazing on well-managed $B$. brizantha in Brazil. Because the animals and the grazing system

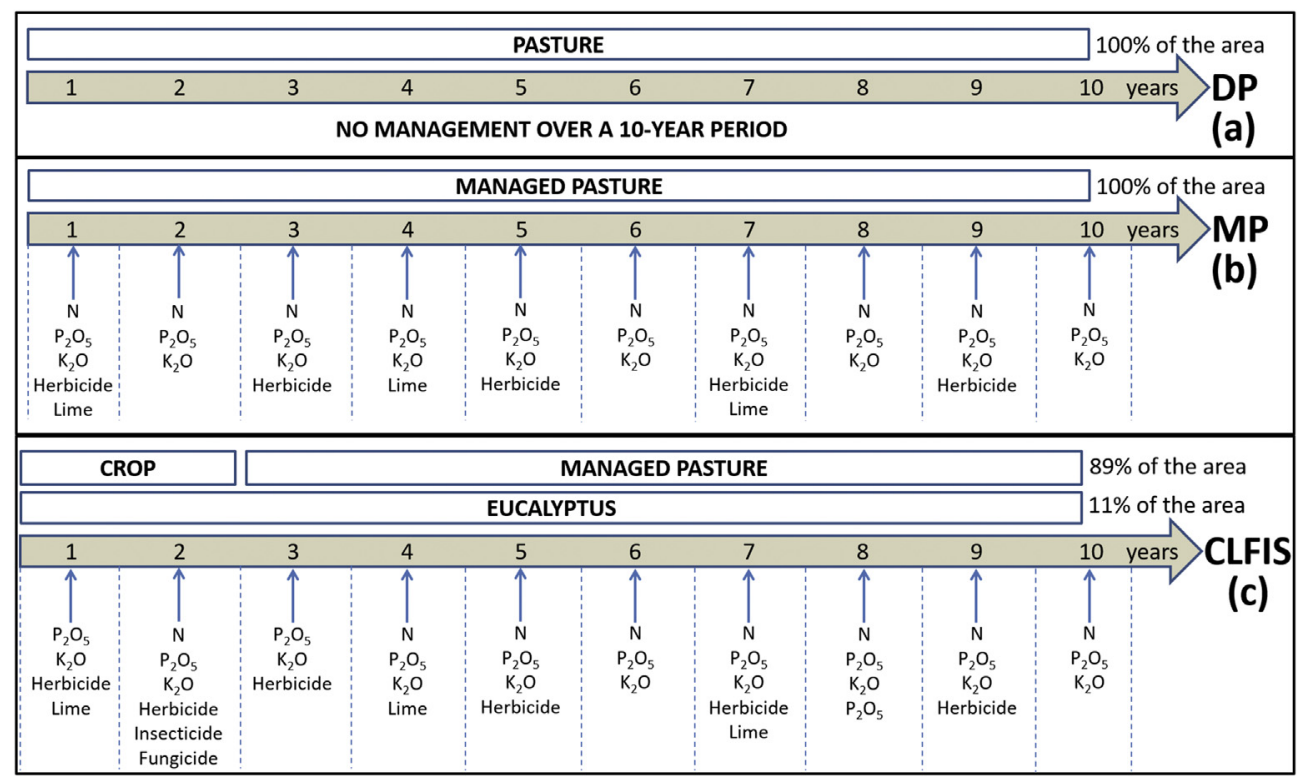

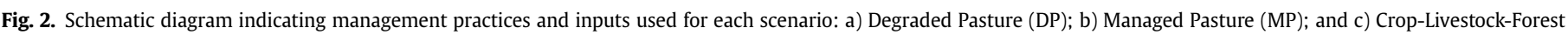
Integration System (CLFIS) over the 10-year period. 
Table 1

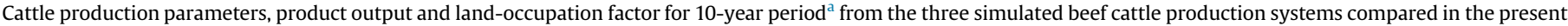
study.

\begin{tabular}{|c|c|c|c|}
\hline & Degraded pasture & Managed pasture & Crop-livestock-forestry integration system \\
\hline Stocking rate (heads $\mathrm{ha}^{-1} \mathrm{yr}^{-1}$ ) & $0.5^{1}$ & $4.0^{2}$ & $3.4^{3}$ \\
\hline Average $\mathrm{LWG}^{\mathrm{C}}\left(\mathrm{kg} \mathrm{head}^{-1}\right.$ day $\left.^{-1}\right)$ & $0.237^{4}$ & $0.616^{5}$ & $0.469^{6}$ \\
\hline Cattle LW yield (kg ha ${ }^{-1}$ year $\left.^{-1}\right)$ & $43^{1}$ & $900^{5}$ & $582^{6}$ \\
\hline $\mathrm{N}^{\mathrm{O}}$ of fattening cycles completed & 3.3 & 5.0 & 3.8 \\
\hline Total cattle yield $\left(\mathrm{kg} \mathrm{ha}^{-1}\right)$ & 433 & 9000 & 4365 \\
\hline \multicolumn{4}{|l|}{ Output of other products } \\
\hline \multicolumn{4}{|l|}{ Crop yields $\left(\mathrm{kg} \mathrm{ha}^{-1}\right)$} \\
\hline Pigeon pea & $\mathrm{na}^{\mathrm{b}}$ & na & na \\
\hline Soybean & na & na & $2820^{7}$ \\
\hline Maize & na & na & $11,400(5700 \times 2)^{7}$ \\
\hline Sorghum & na & na & $10,000(5000 \times 2)^{7}$ \\
\hline Eucalyptus timber $\left(\mathrm{m}^{3} \mathrm{ha}^{-1}\right)$ & na & na & $26^{7,8}$ \\
\hline Land occupation $\left(\mathrm{m}^{2} \mathrm{~kg}^{-1} \mathrm{LWG}\right)$ & 230 & 11.0 & 22.9 \\
\hline
\end{tabular}

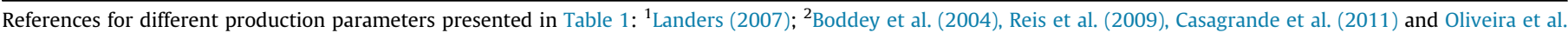
(2012); ${ }^{3}$ Gil et al. (2015); ${ }^{4}$ Euclides et al. (2001); ${ }^{5}$ Corsi et al. (2001); ${ }^{6}$ Salton et al. (2014); ${ }^{7}$ Pacheco et al. (2012); ${ }^{8}$ Dube et al. (2002) and Ofugi et al. (2008).

a 10 -yr period was considered as the economically optimum time span for one production cycle for Eucalyptus based CLFIS in Brazil on the basis of published case studies (Dube et al., 2002; Euclides et al., 2010; Pacheco et al., 2012).

b na: not applicable.

c LWG: Live weight gain.

Table 2

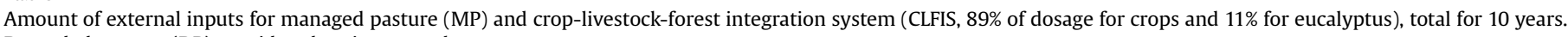
Degraded pasture (DP) considered no input used.

\begin{tabular}{|c|c|c|c|}
\hline \multirow[t]{2}{*}{ Inputs } & \multirow[t]{2}{*}{ Units } & MP & CLFIS \\
\hline & & Amounts & Amounts \\
\hline $\mathrm{N}$ fertilizer (ammonium sulfate) & $\mathrm{kg} \mathrm{N}$ & $150 \times 10$ year $=1500$ & $\begin{array}{l}\left.\text { 1st year }\left(0^{\mathrm{a}}-89^{\mathrm{b}}-11^{\mathrm{c}}\right)=-100 \text { (Avoided from Cajunus cajan } \mathrm{N}\right) \\
\text { 2nd year }\left(0^{\mathrm{a}}+71^{\mathrm{b}}+11^{\mathrm{c}}\right)=82 \\
\text { 3rd year }\left(-80^{\mathrm{a}}+71^{\mathrm{b}}\right)=71(-80 \text { avoided from Brachiaria } \mathrm{N} ;+71 \\
\text { accounted from the second crop) } \\
{ }^{\mathrm{d}} \text { Pasture maintenance: } 150 \times 7 \text { years }=1050\end{array}$ \\
\hline $\mathrm{P}_{2} \mathrm{O}_{5}$ & $\mathrm{~kg} \mathrm{P}_{2} \mathrm{O}_{5}$ & 50 per year $=500$ & $\begin{array}{l}\text { 1st year }\left(100^{\mathrm{a}}+54^{\mathrm{b}}+11^{\mathrm{c}}\right)=165 \\
\text { 2nd year }\left(54^{\mathrm{a}}+54^{\mathrm{b}}\right)=108 \\
\text { 3rd year }\left(54^{\mathrm{a}}+54^{\mathrm{b}}\right)=108 \\
{ }^{\mathrm{d}} \text { Pasture maintenance: } 50 \times 7 \text { times }(\text { each year })=350\end{array}$ \\
\hline $\mathrm{K}_{2} \mathrm{O}$ & $\mathrm{kg} \mathrm{K} \mathrm{K}_{2} \mathrm{O}$ & $50 \times 10$ years $=500$ & $\begin{array}{l}\text { 1st year }\left(89^{\mathrm{a}}+89^{\mathrm{b}}+11^{\mathrm{c}}\right)=189 \\
\text { 2nd year }\left(89^{\mathrm{a}}+89^{\mathrm{b}}\right)=178 \\
\text { 3rd year }\left(89^{\mathrm{a}}+89^{\mathrm{b}}\right)=178 \\
{ }^{\mathrm{d}} \text { Pasture maintenance: } 7 \text { years } \times 54=378\end{array}$ \\
\hline Herbicides (active ingredient) & $\mathrm{kg}$ or L a.i. & $1.44 \times 5$ years $($ each 2 years $)=7.2(2,4,5 \mathrm{~T})$ & 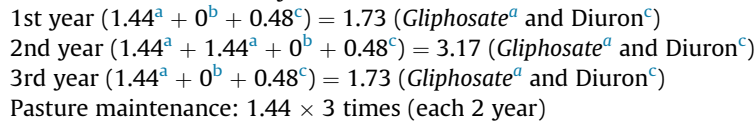 \\
\hline Animal feed supplement & $\mathrm{kg}$ & 9480 & 6043 \\
\hline Insecticides (Carbaril) & $\mathrm{kg} \mathrm{L}^{-1}$ & & 2nd year ( 2 applications $\times 200 \mathrm{~g}$ a.i. ha $\left.{ }^{-1}\right)^{\mathrm{a}}=0.400 \mathrm{~kg}$ a.i. \\
\hline Fungicides (Benomyl) & $\mathrm{kg} \mathrm{L}^{-1}$ & & 2nd year $\left(0.25 \mathrm{~g}\right.$ a.i. ha ${ }^{-1} \times 3$ times $\left.^{\mathrm{a}}\right)=0.75$ \\
\hline Dolomite & $\mathrm{Mg}$ & $2 \mathrm{Mg}$ each 3 years $=6$ & $2 \mathrm{Mg}$ each 3 years $=6$ ( $2 \mathrm{Mg}$ for crops and 4 for pasture $)$ \\
\hline Diesel oil & $\mathrm{L}$ & 224 & 260 (Crops), 19 (Eucalyptus) and 125 (Pasture maintenance) \\
\hline
\end{tabular}

1st year suggested crop rotation: Pigeon pea (first crop); Maize + Brachiaria (second crop).

2nd year suggested crop rotation: Soybean (first crop); Sorghum + Brachiaria (second crop).

3rd year suggested crop rotation: Maize (first crop); Sorghum + Brachiaria (second crop).

a.i. - active ingredient.

a First crop of the year: $89 \%$ of occupied area and respective dosage.

b Second crop of the year: $89 \%$ of occupied area and respective dosage.

c Eucalyptus: $11 \%$ of occupied area and respective dosage.

d Pasture: $89 \%$ of occupied area and respective dosage.

studied by Demarchi et al. (2003) closely represent the animals and improved pasture conditions in the MP and CLFIS scenarios in this study, we selected the average enteric $\mathrm{CH}_{4}$ emission factor of $52 \mathrm{~kg}$ $\mathrm{CH}_{4}$ head $^{-1} \mathrm{yr}^{-1}$ in view of the moderate improvements in enteric $\mathrm{CH}_{4}$ emissions from grazing beef cattle that could be achievable with improved feed quality and dietary supplements (IPCC, 2014).

For estimating $\mathrm{CH}_{4}$ emissions from manure deposited on pasture, IPCC (2006) Tier 1 method was applied. The term 'manure' includes both dung and urine produced by grazing beef cattle. The default $\mathrm{CH}_{4}$ emission factor of $1 \mathrm{~kg} \mathrm{CH}_{4}$ head ${ }^{-1} \mathrm{yr}^{-1}$ for grazing beef cattle recommended for Latin America with an average annual temperature of $22^{\circ} \mathrm{C}$ (IPCC, 2006) was used.

\subsection{Direct and indirect $\mathrm{N}_{2} \mathrm{O}$ emissions from manure}

The estimation of $\mathrm{N}_{2} \mathrm{O}$ emissions from manure excreted on pasture was performed using the country-specific annual $\mathrm{N}$ excretion rate and the $\mathrm{N}_{2} \mathrm{O}-\mathrm{N}$ emission factor for grazing beef cattle derived from Brazilian research, an approach encouraged by IPCC (2006). In a recent study, Lessa et al. (2014) measured the 
fraction of $\mathrm{N}$ lost as $\mathrm{N}_{2} \mathrm{O}$ to be approximately $0.012 \mathrm{~g} \mathrm{~N} \mathrm{~g}^{-1} \mathrm{~N}$ for urine (60\%) and $0.001 \mathrm{~g} \mathrm{~N} \mathrm{~g}^{-1} \mathrm{~N}$ for dung (40\%). Based on this research, they derived an annual average $\mathrm{N}_{2} \mathrm{O}-\mathrm{N}$ emission factor of approximately $0.007 \mathrm{~g} \mathrm{~N} \mathrm{~g}^{-1}$ excreted $\mathrm{N}$. Their results also indicated that an average annual $\mathrm{N}$ excretion by beef cattle was approximately $40 \mathrm{~kg} \mathrm{~N}$ head $^{-1}$, a rate within the range of $\mathrm{N}$ excretion reported by Boddey et al. (2004). Based on these results, an average emission factor of $0.59 \mathrm{~kg} \mathrm{~N}_{2} \mathrm{O}$ head ${ }^{-1} \mathrm{yr}^{-1}$ (Lessa et al., 2014) was applied for all grazing pasture scenarios in this study, assuming $1 \%$ of volatilized $\mathrm{N}$ was lost as $\mathrm{N}_{2} \mathrm{O}$ (IPCC, 2006). Lessa et al. (2014) also reported that there is no significant leaching and run-off losses of $\mathrm{N}$ excreted by grazing beef cattle during the dry period; therefore, we assumed insignificant leaching and run-off losses of excreted $\mathrm{N}$ for this analysis.

\subsection{Direct and indirect $\mathrm{N}_{2} \mathrm{O}$ emissions from synthetic $\mathrm{N}$ fertilizer and crop residues}

Generally, fertilizer is not used on extensive pastures with a low stocking rate in Brazil. However, when the aim is for higher meat production, the rate of $\mathrm{N}$ application may vary from 70 to over $400 \mathrm{~kg} \mathrm{~N} \mathrm{ha}^{-1} \mathrm{yr}^{-1}$ (Balieiro Neto et al., 2009a). In this analysis, an average rate of $150 \mathrm{~kg} \mathrm{~N} \mathrm{ha}^{-1} \mathrm{yr}^{-1}$, split into three applications per year (applied using a tractor) during the rainy season, was assumed for the MP scenario, for a total of $1500 \mathrm{~kg} \mathrm{~N} \mathrm{ha}^{-1}$ over a 10 -yr period (Table 2). The same application rate of $150 \mathrm{~kg} \mathrm{~N} \mathrm{ha}^{-1} \mathrm{yr}^{-1}$ for pasture maintenance was assumed for the CLFIS scenario over the 7.5-yr period. The most widely used $\mathrm{N}$ fertilizer types in Brazil are urea $(44-46 \% \mathrm{~N})$, ammonium sulfate $(20-21 \% \mathrm{~N})$ and ammonium nitrate (32-33\% N). Based on Embrapa (2006) recommendations, we assumed that $\mathrm{N}$ was supplied as ammonium sulfate (Table 2). For the CLFIS scenario, the amount of synthetic fertilizer N (SFN) used for crops during the first 2.5 years (Fig. 2c and Table 2) was $153 \mathrm{~kg} \mathrm{~N} \mathrm{ha}{ }^{-1}$, whereas the SFN used for pasture maintenance during the remaining 7.5-yr period was $1050 \mathrm{~kg} \mathrm{~N} \mathrm{ha}^{-1}$. The methodology used to calculate $\mathrm{N}_{2} \mathrm{O}$ emissions from $\mathrm{N}$ fertilizer follows IPCC (2006). Emission factors are $0.01 \mathrm{~kg} \mathrm{~N}_{2} \mathrm{O}-\mathrm{N} \mathrm{kg}^{-1} \mathrm{~N}$ for direct $\mathrm{N}_{2} \mathrm{O}$ emissions, $0.001 \mathrm{~kg} \mathrm{~N} \mathrm{~N}_{2} \mathrm{O}-\mathrm{N} \mathrm{kg}^{-1} \mathrm{~N}$ for indirect $\mathrm{N}_{2} \mathrm{O}$ emissions by volatilization and $0.00225 \mathrm{~kg} \mathrm{~N}_{2} \mathrm{O}-\mathrm{N} \mathrm{kg}^{-1} \mathrm{~N}$ for leaching and runoff of applied $\mathrm{N}$.

The total $\mathrm{N}_{2} \mathrm{O}$ emissions associated with $\mathrm{N}$ released from crop residues and pasture renewal include the direct and indirect emissions due to $\mathrm{N}$ mineralized from crop residue decomposition (IPCC, 2006). The amount of $\mathrm{N}$ from crop residues returned to soil was estimated based on average crop yields (on a dry matter basis), default factors for the ratios of above/below ground residue yield and the $\mathrm{N}$ content of the residue returned to the soil (IPCC, 2006). In the CLFIS scenario, estimates were made for all crops grown in the initial 2.5-yr period and for the Brachiaria pasture. Maize, sorghum and soybean $\mathrm{N}$ content were estimated assuming an average grain yield of $5700 \mathrm{~kg} \mathrm{ha}^{-1}, 5000 \mathrm{~kg} \mathrm{ha}^{-1}$ and $2820 \mathrm{~kg} \mathrm{ha}^{-1}$, respectively (Pacheco et al., 2012).

According to Embrapa (2007), B. brizanta cv. Marandu produces annual dry matter (DM) yields close to $8.0 \mathrm{Mg} \mathrm{ha}^{-1}$ and may reach up to $20.0 \mathrm{Mg} \mathrm{ha}^{-1}$ with the application of fertilizer. Hence, for this study, we used an average dry matter yield of $11.8 \mathrm{Mg} \mathrm{DM}^{-1} \mathrm{yr}^{-1}$ for the above-ground biomass of Brachiaria for both the rainy and dry seasons, with an average $\mathrm{N}$ content of $12.9 \mathrm{~g} \mathrm{~N} \mathrm{~kg}^{-1} \mathrm{DM}$. As a result, $152 \mathrm{~kg} \mathrm{~N} \mathrm{ha}^{-1} \mathrm{yr}^{-1}$ was returned to the soil due to the desiccation of Brachiaria. Here, we assumed that all residues from Brachiaria mineralized after a period of one year (Torres et al., 2008).

The $\mathrm{CO}_{2}$ emissions prevented from the production of SFN were accounted for due to the $\mathrm{N}$ content of pigeon pea, the $\mathrm{N}$ accumulated by maize plants ( 1 st year $-2 \mathrm{nd}$ crop $-100 \mathrm{~kg} \mathrm{~N} \mathrm{ha}^{-1}$ ) and the
Brachiaria $\mathrm{N}$ content to maize plants (3rd year $-80 \mathrm{~kg} \mathrm{~N} \mathrm{ha}^{-1}$; Table 2). Pigeon pea, as the first crop in the CLFIS, can fix large amounts of $\mathrm{N}_{2}$ from the atmosphere. For example, Salmi et al. (2006) reported dry matter production ranging from 4.67 to $5.95 \mathrm{Mg} \mathrm{DM} \mathrm{ha}^{-1}$ with an average of $5.3 \mathrm{Mg} \mathrm{DM} \mathrm{ha}^{-1}$ and N content ranging from 188 to $261 \mathrm{~kg} \mathrm{ha}^{-1}$ (3.8-4.4\% of $\mathrm{N}$ from DM). Here we assumed the average $\mathrm{N}$-fixation by pigeon pea to be $227 \mathrm{~kg} \mathrm{~N} \mathrm{ha}^{-1}$

\section{5. $\mathrm{CO}_{2}$ emissions due to the use of other inputs in MP and CLFIS}

In addition to the use of SFN, several other inputs are used in the MP and CLFIS scenarios. These include phosphate and potash fertilizer, herbicides, insecticides, fungicides and lime applications. Souza and Lobato (2002), and Macedo (2005) demonstrated that phosphorus is one of the most critical nutrients required for pasture sustainability. The annual rates and the total amounts of $\mathrm{P}_{2} \mathrm{O}_{5}$ and $\mathrm{K}_{2} \mathrm{O}$ applied over a 10 -yr cycle for the pasture in the MP, and for annual crops (2.5-yr period), Eucalyptus and pasture (7.5-yr) in the CLFIS are presented in Fig. 2 and Table 2.

The emission factors applied for the calculation of GHG emissions from the production of nitrogen, phosphorus and potassium fertilizers were $3.97 \mathrm{~kg} \mathrm{CO}_{2} \mathrm{eq} \mathrm{kg}{ }^{-1} \mathrm{~N}, 1.3 \mathrm{~kg} \mathrm{CO}_{2} \mathrm{eq} \mathrm{kg}{ }^{-1} \mathrm{P}_{2} \mathrm{O}_{5}$ and $0.71 \mathrm{~kg} \mathrm{CO}_{2} \mathrm{eq} \mathrm{kg} \mathrm{kg}^{-1} \mathrm{~K}_{2} \mathrm{O}$ (Macedo et al., 2008), which correspond to the emission factors used in the EBAMM and GREET models. In addition to fertilizer, liming is recommended for the maintenance of optimum soil pH when restoring degraded pastures. For B. brizantha, Werner et al. (1996) recommended a soil base saturation (BS) of $60 \%$ for planting or $50 \%$ for pasture maintenance. Here we assumed that lime was applied only for MP and CLFIS (Fig. 2b and c; Table 2).

The protein feed supplement provided to cattle in the dry season in MP and CLFIS consists of $82 \%$ maize bran, $14 \%$ milled soybean grain, $3 \%$ urea and $1 \%$ mineral salt (Detmann et al., 2004). Estimated for an average animal weighing $325 \mathrm{~kg}$, total protein supplement, when offered at a rate of $4 \mathrm{~g} \mathrm{~kg}^{-1}$ of body weight (Oliveira et al., 2012), is $237 \mathrm{~kg} \mathrm{head}^{-1}$ for a 6-month period (Table 2). Accordingly, the amount of each component of the supplement provided per animal in the MP and CLFIS scenarios for a 6-month duration is $194 \mathrm{~kg} \mathrm{head}^{-1}$ of maize bran, $33 \mathrm{~kg} \mathrm{head}^{-1}$ of milled soybean grain and $7 \mathrm{~kg} \mathrm{~N}$ head $^{-1}$ of urea. GHG emissions associated with the production of these protein feed supplements was estimated taking into account the use of external inputs to grow crops in CLFIS (fertilizers, $\mathrm{N}$ from crop-rotation residues, lime, diesel, and pesticides) and respective crop yields. The resulting emission factor was $0.40 \mathrm{~kg} \mathrm{CO}_{2} \mathrm{eq} \mathrm{kg} \mathrm{kg}^{-1}$ of grain, considering $20 \%$ of oil was extracted from soybean. In addition, GHG emissions associated with the urea component of the feed supplement were calculated using the IPCC (2006) default emission factor for urea production. The total amount of urea provided to cattle in feed supplements was $280 \mathrm{~kg}$ urea ha ${ }^{-1}$ in the MP over 10 years and $181 \mathrm{~kg}$ urea ha ${ }^{-1}$ in the CLFIS over 7.5 years.

\section{6. $\mathrm{CO}_{2}$ emissions due to fossil fuel use (diesel oil) in agricultural operations}

The fossil fuel used in the MP and CLFIS scenarios included the diesel consumed for agricultural machinery, tractors and harvesters during field operations (Table 2 ) over 10 years. We used the national emission factors from CETESB (2011) to calculate GHG emissions caused by the burning of fuel. The emissions associated with diesel production were calculated using the emission factor of Macedo et al. (2008). The amounts of diesel consumed in each pasture-management system and the operations considered were based on Macedo et al. (2008) and De Figueiredo and La Scala Jr. et al. (2011) (Table 2). The calculations for each of the agricultural 
operations considered the tractor's power (HP), work capacity (ha $\mathrm{h}^{-1}$ ) and diesel consumption $\left(\mathrm{L} \mathrm{h}^{-1}\right.$; adapted from Macedo et al., 2004), which in CLFIS were separated for cattle, crops and Eucalyptus (Table 2).

\subsection{Potential for soil carbon accumulation}

Studying the effect of pasture and crop-livestock rotations on soil C stocks in Brazil, Carvalho et al. (2010) reported an average accumulation rate of $0.44 \mathrm{MgC} \mathrm{ha} \mathrm{Mr}^{-1}$ on a $15-\mathrm{yr}$ old pasture under optimum management and fertilizer application. The same authors showed that integrated crop-livestock systems often act as a sink for $\mathrm{C}$ with accumulation rates up to $2.85 \mathrm{Mg} \mathrm{C} \mathrm{ha}^{-1} \mathrm{yr}^{-1}$. However, for this analysis, we considered a modest soil $\mathrm{C}$ accumulation rate of $0.44 \mathrm{MgC} \mathrm{ha}^{-1} \mathrm{yr}^{-1}$ (e.g., $16,333 \mathrm{~kg} \mathrm{CO}_{2} \mathrm{ha}^{-1}$ in 10 years) for both MP and CLFIS. No-till farming (NT), in rotation with pasture, is another practice that may be incorporated into the CLFIS to benefit the physical, chemical and biological properties of soil (García-Préchac et al., 2004; Marchão et al., 2007).

\subsection{Biomass C sinks - technical potential for eucalyptus in integrated systems}

The United Nations Framework Convention on Climate Change (UNFCCC) defines $C$ sequestration as the process of removing $C$ from the atmosphere $\left(\mathrm{CO}_{2}-\mathrm{C}\right)$ and depositing it in a reservoir in long-lived pools (UNFCCC, 2007, 2013). Methods of $\mathrm{CO}_{2}$ removal that are proposed by IPCC (2013) include afforestation/reforestation, no-till agriculture, conservation agriculture, agroforestry and the sequestration of $C$ in wood used in buildings. In Brazil, farmers generally use Eucalyptus wood for fences, corrals, gates or timber for different construction activities (i.e., doors, tables and roofs), which could be considered secure $C$ pools. In addition, Eucalyptus wood can be used as feedstock for renewable energy generation, thus contributing to mitigating climate forcing (IPCC, 2014).

According to Brazilian case studies, CLFIS with 250-500 Eucalyptus trees $\mathrm{ha}^{-1}$ produce an average annual wood yield from 24 to $28 \mathrm{~m}^{3} \mathrm{ha}^{-1}$ in a 10-12 yr production cycle (Dube et al., 2002; Ofugi et al., 2008; Pacheco et al., 2012). Assuming an average timber yield of $26 \mathrm{~m}^{3}$ ha $^{-1}$ (Table 1 ), at a wood density of $0.491 \mathrm{Mg} \mathrm{m}^{-3}$ for Eucalyptus hybrid urograndis (E. grandis x E. urophylla) (Gominho et al., 2001) and an average $\mathrm{C}$ content of $0.45 \mathrm{Mg} \mathrm{C} \mathrm{Mg}^{-1}$ wood would represent an average $C$ sequestration rate of approximately $4.75 \mathrm{Mg} \mathrm{C} \mathrm{ha}^{-1} \mathrm{yr}^{-1}$ (i.e., $17.4 \mathrm{Mg} \mathrm{CO}_{2} \mathrm{ha}^{-1} \mathrm{yr}^{1}$ ). Based on these results, an annual $\mathrm{C}$ sequestration potential rate of $17 \mathrm{Mg} \mathrm{CO}_{2} \mathrm{ha}^{-1}$ $\mathrm{yr}^{1}$ for Eucalyptus wood was considered for the CLFIS scenario, corresponding to a sequestration potential of $170,000 \mathrm{~kg} \mathrm{CO} 2 \mathrm{eq}$ ha $^{-1}$ for a $10-y r$ production cycle.

\section{Results and discussion}

\subsection{Greenhouse gas emissions contributed by beef cattle}

In our analysis, the estimated total GHG emissions were highest in the MP system with $84,541 \mathrm{~kg} \mathrm{CO}_{2} \mathrm{eq} \mathrm{ha}{ }^{-1}$ over the 10 -yr period, followed by $64,519 \mathrm{~kg} \mathrm{CO}_{2} \mathrm{eq} \mathrm{ha}{ }^{-1}$ in the CLFIS and $8004 \mathrm{~kg} \mathrm{CO}_{2} \mathrm{eq}$ ha $^{-1}$ in the DP (Fig. 3 and Table 3 ). Because no external inputs were used in the DP system, GHG contributed by beef cattle constituted all GHG emissions in this system, with $87 \%$ as $\mathrm{CH}_{4}$ from enteric fermentation and the remainder from the manure deposited on pasture. In contrast, $\mathrm{CH}_{4}$ from enteric fermentation contributed $61 \%$ of the total GHG in the MP and 51\% of the total GHG in the CLFIS over the 10-yr period (Fig. 3 and Table 3). Our results indicate that $\mathrm{CH}_{4}$ from enteric fermentation is the largest proportion of total GHG emissions in contrasting beef cattle production systems, an

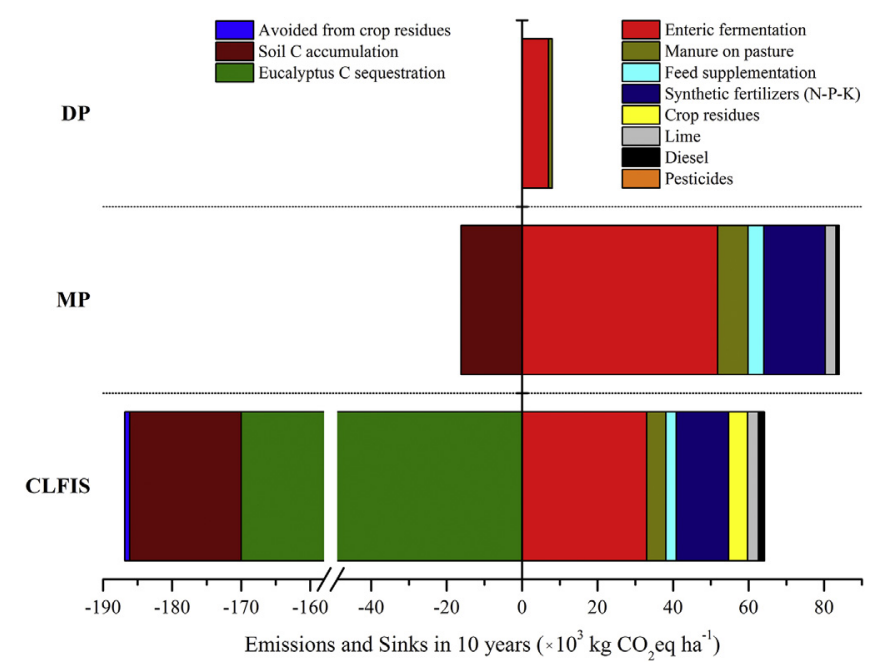

Fig. 3. Greenhouse gas emissions $\left(\times 10^{3} \mathrm{~kg} \mathrm{CO}_{2} \mathrm{eq} \mathrm{ha}{ }^{-1}\right)$ per source (right bars) and potential for $C$ sink (left bars) accumulated over a 10-year period for each pasture management system: Degraded Pasture (DP), Managed Pasture (MP) and CropLivestock-Forest-Integration System (CLFIS) in Brazil.

observation common to all ruminant meat-production systems (Peters et al., 2010; Bustamante et al., 2012; Ripple et al., 2014). Furthermore, Cerri et al. (2009) showed that $\mathrm{CH}_{4}$ from enteric fermentation was the third-highest contributing sector to Brazilian GHG emissions in 2005, increasing 26.1\% since 1994 and representing $12 \%$ of the total Brazilian GHG emissions.

The $\mathrm{CH}_{4}$ emission factor for enteric fermentation adopted in MP and CLFIS was $52 \mathrm{~kg} \mathrm{CH}_{4}$ head ${ }^{-1} \mathrm{yr}^{-1}$, which was based on experimental data from beef cattle grazing under similar climatic conditions on well-managed pasture in Brazil (Demarchi et al., 2003). This emission factor is approximately 7\% lower than the default emission factor recommended by IPCC (2006) for beef cattle grazing on extensive pastures in Latin America $\left(56 \mathrm{~kg} \mathrm{CH}_{4}\right.$ head $\left.^{-1} \mathrm{yr}^{-1}\right)$, which was applied for our DP scenario. The use of extensively grazed unmanaged pasture is a common feature in traditional beef cattle production systems in Brazil (Millen and Arrigoni, 2013). These pastures are characterized by large tracts of land with little subdivision, where cattle are allowed to graze continuously without feed supplementation, and the pasture is not fertilized (Landers, 2007). These pastures are generally low in nutritive quality and typified with relatively high enteric $\mathrm{CH}_{4}$ emissions per unit weight of dry matter consumed by cattle (Berndt and Tomkins, 2013). Several strategies have been suggested for mitigating enteric $\mathrm{CH}_{4}$ emissions from pasture-based beef production systems in Brazil, which include increasing the nutritive quality and digestibility of pasture through improved management practices, such as fertilizer and lime application and rotational grazing (Demarchi et al., 2003; Mandarino et al., 2014), and nutritional strategies such as providing grains and protein supplements (De Oliveira et al., 2007; Balieiro Neto et al., 2009b; Berchielli et al., 2011). Presenting measurement and mitigation options of $\mathrm{CH}_{4}$ emissions from beef cattle in tropical grazing systems from Australia and Brazil, Berndt and Tomkins (2013) showed values that ranged from 21.5 to $65.3 \mathrm{~kg} \mathrm{CH}_{4}$ head ${ }^{-1} \mathrm{yr}^{-1}$ (varying feed supplements). Thus, it is emphasized that these results indicate a wide range of potential mitigation strategies under pasture conditions in Brazil.

Very limited experimental data are available on enteric $\mathrm{CH}_{4}$ emissions from beef cattle on pasture integrated with CLFIS in Brazil. Therefore, we used the same enteric $\mathrm{CH}_{4}$ emission factor 
Table 3

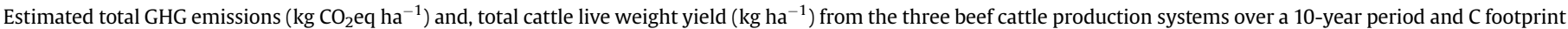

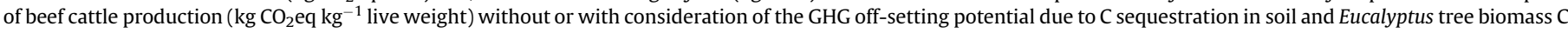

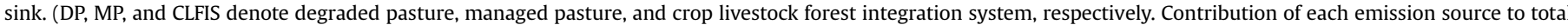
emissions as a \% is also shown).

\begin{tabular}{|c|c|c|c|c|c|c|c|c|}
\hline \multicolumn{2}{|l|}{ Emission sources } & Gases & DP & $\%$ & MP & $\%$ & CLFIS & $\%$ \\
\hline \multicolumn{2}{|l|}{ Enteric fermentation } & $\mathrm{CH}_{4}$ & 7000 & 87 & 51,790 & 61 & 33,016 & 51 \\
\hline \multirow{2}{*}{\multicolumn{2}{|c|}{ Manure on pasture }} & $\mathrm{CH}_{4}$ & 125 & 2 & 1000 & 1 & 638 & 1 \\
\hline & & $\mathrm{N}_{2} \mathrm{O}$ & 879 & 11 & 7033 & 8 & 4483 & 7 \\
\hline Feed supplement & & $\mathrm{CO}_{2}$ & & & 4792 & 6 & 3064 & 5 \\
\hline \multirow[t]{4}{*}{ Synthetic Fertilizers } & $\mathrm{N}$ & $\mathrm{N}_{2} \mathrm{O}$ & - & & 9307 & 11 & 7464 & 12 \\
\hline & & $\mathrm{CO}_{2}$ & - & & 5955 & 7 & 4776 & 7 \\
\hline & $\mathrm{K}_{2} \mathrm{O}$ & $\mathrm{CO}_{2}$ & - & & 355 & 0 & 655 & 1 \\
\hline & $\mathrm{P}_{2} \mathrm{O}_{5}$ & $\mathrm{CO}_{2}$ & - & & 650 & 1 & 950 & 1 \\
\hline Crop residues & & $\mathrm{N}_{2} \mathrm{O}$ & - & & - & 0 & 5008 & 8 \\
\hline Insecticides & & $\mathrm{CO}_{2}$ & - & & - & 0 & 5 & - \\
\hline Herbicides & & $\mathrm{CO}_{2}$ & - & & 70 & 0 & 264 & 0 \\
\hline Fungicides & & $\mathrm{CO}_{2}$ & - & & - & 0 & 22 & - \\
\hline Lime & & $\mathrm{CO}_{2}$ & - & & 2860 & 3 & 2860 & 4 \\
\hline Diesel & & $\mathrm{CO}_{2}$ & - & & 729 & 1 & 1314 & 2 \\
\hline Total emissions & & & 8004 & 100 & 84,541 & 100 & 64,519 & 100 \\
\hline Emissions from cattle & & & 8004 & 100 & 84,541 & 100 & 54,965 & 59 \\
\hline Other emissions ${ }^{\mathrm{b}}$ & & & - & & - & - & 9554 & 41 \\
\hline Cattle live weight yield & & & 433 & & 9000 & & 4365 & \\
\hline Crop yield $\left(\mathrm{kg} \mathrm{ha}^{-1}\right)$ & & & - & & - & & 23,659 & \\
\hline Eucalyptus wood yield & & & - & & - & & 26 & \\
\hline $\mathrm{C}$ footprint of cattle ( $\mathrm{W}$ & ff-setting potential) & & 18.5 & & 9.4 & & 12.6 & \\
\hline Potential for soil $\mathrm{C}$ acc & $\left.\mathrm{CO}_{2} \mathrm{ha}^{-1}\right)$ & & - & & 16,133 & & 16,133 & \\
\hline Potential for Eucalyptu & ion $\left(\mathrm{kg} \mathrm{CO} \mathrm{Ca}^{-1}\right)$ & & - & & - & & 170,000 & \\
\hline Avoided (-) emissions & $\left(\mathrm{kg} \mathrm{CO} \mathrm{ha}^{-1}\right)$ & & - & & - & & 715 & \\
\hline $\mathrm{C}$ footprint of cattle ( $\mathrm{W}$ & tting potential) & & 18.5 & & 7.6 & & -28.1 & \\
\hline
\end{tabular}

${ }^{a} \mathrm{CH}_{4}$ from enteric fermentation, $\mathrm{N}_{2} \mathrm{O}$ from manure, $\mathrm{CH}_{4}$ from manure and emissions from pasture management (e.g., agricultural inputs and diesel) in MP and CLFIS, while in DP no pasture management was performed.

b Emissions from crops and Eucalyptus (e.g., agricultural inputs and diesel).

used for cattle in MP as a result of improved forage quality and better digestibility. Recently, Mandarino et al. (2014), studying enteric $\mathrm{CH}_{4}$ emissions by Nellore heifers (322 kg of live weight) grazing B. brizantha cv. Piatã, in Eucalyptus-based CLFIS, reported approximately $97 \mathrm{~g} \mathrm{CH}_{4}$ animal $^{-1}$ day $^{-1}$, with a mean dry matter digestibility of $55 \%$ and a dry matter intake of approximately $6.0 \mathrm{~kg}$ animal $^{-1}$ day $^{-1}$. If extrapolated for a whole year, this value is approximately $35 \mathrm{~kg} \mathrm{CH}_{4}$ head $^{-1} \mathrm{yr}^{-1}$, indicating a potentially lower enteric $\mathrm{CH}_{4}$ emission factor for cattle grazing in CLFIS.

$\mathrm{N}_{2} \mathrm{O}$ emissions from manure deposited on pasture by grazing cattle contributed approximately $11 \%$ of the total GHG in DP and approximately $7 \%$ of the total GHG in MP and CLFIS (Fig. 3 and Table 3). Our estimates of $\mathrm{N}_{2} \mathrm{O}$ emissions are based on Brazilspecific data collected from long-term field experiments in central Brazil (Boddey et al., 2004; Lessa et al., 2014), where pasturebased beef-production systems analyzed are adopted in this study (Pacheco et al., 2012; Salton et al., 2014). Nitrogen excretion rates and $\mathrm{N}_{2} \mathrm{O}$ emissions factors (40 kg N excreted animal ${ }^{-1} \mathrm{yr}^{-1}$ and $0.007 \mathrm{~g} \mathrm{~N} \mathrm{~g}^{-1}$ excreted $\mathrm{N}$, respectively) reported by Lessa et al. (2014) are at the lower end of the uncertainty range recommended by IPCC (2006) but well below the mean value of $0.02 \mathrm{~g} \mathrm{~N} \mathrm{~g}^{-1}$ excreted N. Comparing the values reported by Lessa et al. (2014) with those of the IPCC guidelines (including the indirect $\mathrm{N}_{2} \mathrm{O}$ emissions from leaching and runoff, which are normally negligible in relatively drier seasonal conditions in Brazilian pastures), the IPCC default emission factor is two times higher, 1.52-2.67 $\mathrm{kg} \mathrm{N}_{2} \mathrm{O}$ head ${ }^{-1} \mathrm{yr}^{-1}$, thus indicating the importance of using countryspecific data for this analysis. $\mathrm{CH}_{4}$ emissions from manure deposited on pasture contributed only a minor proportion $(<2 \%)$ to the total GHG emissions in all three scenarios.

Reviewing options to abate $\mathrm{N}_{2} \mathrm{O}$ emissions from ruminant production systems, Eckard et al. (2010) stated only few mitigation options are available for extensive grazing systems. The majority of $\mathrm{N}_{2} \mathrm{O}$ emissions from manure deposited on pasture is derived from the urine fraction of manure (Lessa et al., 2014), and the effective $\mathrm{N}$ deposition rate in urine patches can be considerably higher than the general $\mathrm{N}$ application rates soil-plant systems can efficiently use (Eckard et al., 2010). Practices that encourage a uniform distribution of manure deposition across grazing areas, such as rotational grazing with an optimum stocking density, may contribute to reduce $\mathrm{N}_{2} \mathrm{O}$ emissions.

\subsection{Greenhouse gas emissions associated with crop production and pasture maintenance}

These GHG emissions resulted from the use of external inputs for crop production during the initial 2.5-yr period of the CLFIS and for pasture maintenance in MP and CLFIS. Of these GHG emissions, the largest proportion of GHG was contributed by the use of SFN (Table 3). Applying SFN as ammonium sulfate in these two systems contributed approximately $11 \%$ of the total GHG over the 10 years as $\mathrm{N}_{2} \mathrm{O}$ emissions from soil and another $7 \%$ due to the off-farm energy consumed in the production and supply of SFN (Table 3). Different sources of $\mathrm{N}$ are used for pasture maintenance in Brazil, generally during the wet season. Adding urea to soils leads to an additional release of $\mathrm{CO}_{2}$ that is fixed in the industrial production process in the order of $0.733 \mathrm{~kg} \mathrm{CO}_{2} \mathrm{~kg}^{-1}$ urea (IPCC, 2006). By preventing the use of urea as an $\mathrm{N}$ fertilizer source, it is possible to avoid additional $\mathrm{CO}_{2}$ emission from this source, which would be approximately $1100 \mathrm{~kg} \mathrm{CO} 2$ in MP (for the use of $1500 \mathrm{~kg} \mathrm{~N}$ fertilizer over 10 years) and $880 \mathrm{~kg} \mathrm{CO}$ in CLFIS (for the use of approximately $1200 \mathrm{~kg} \mathrm{~N}$ over 10 years).

Avoiding urea could be regarded as a strategy for reducing GHG emissions from the application of SFN to pasture. However, ammonium sulfate could induce soil acidification, and regular lime application is an essential practice for attenuating this issue and for improving pasture growth (Oliveira et al., 2003; Don et al., 2011). Our analysis indicated that lime application contributed 3-4\% GHG 
to the total emissions in these two production systems (Table 3). The rate, source, and frequency of fertilizer application are important management factors that affect the efficiency of pasture growth and potential $\mathrm{N}_{2} \mathrm{O}$ losses (Eckard et al., 2010). Euclides et al. (2010) presented recommendations for pasture fertilization based on Macedo (2004), highlighting that there is a lack of research for better fertilization practices in pasture maintenance.

GHG emissions associated with the production and application of $\mathrm{P}_{2} \mathrm{O}_{5}$ and $\mathrm{K}_{2} \mathrm{O}$ accounted for only a very small proportion $(<2 \%)$ of the total GHG emissions in MP and CLFIS over the 10 -yr period (Table 3). It is important to note that phosphorus is one of the most limiting nutrients for pasture establishment and sustainability in Brazil (Souza and Lobato, 2002; Macedo, 2005), and the rate of $\mathrm{P}_{2} \mathrm{O}_{5}$ should be adjusted to support higher animal live weight gain in terms of $\mathrm{kg} \mathrm{ha}^{-1}$. Based on our analysis, $\mathrm{P}_{2} \mathrm{O}_{5}$ application does not contribute appreciably higher GHG emissions to the total, compared with nitrogen fertilization, but it leads to improved pasture growth and higher live weight gains. All other external inputs (herbicides, insecticides, fungicides and diesel use) contributed very small proportions $(<2 \%)$ of the total GHG emissions in the two systems (Table 3 ).

The use of feed supplements for improving diet quality for cattle during the dry season ( 6 months per year) contributed approximately $6 \%$ of the total GHG in MP and approximately $5 \%$ of the total GHG in CLFIS (Table 3). Using protein feed supplements for cattle during the dry season is an important strategy to improve cattle's LW gain, leading to productive precocity and a shortened age to slaughter (Paulino et al., 2001).

In the CLIFS scenario, some additional GHG emissions occurred in the form of direct and indirect $\mathrm{N}_{2} \mathrm{O}$ emissions from the crop residue decomposition, and $\mathrm{N}$ returned to the soil in this process. Such emissions, estimated to be approximately $8 \%$ of the total over the initial 2.5-yr cropping period in CLFIS (Fig. 3 and Table 3), resulted from $\mathrm{N}$ released from pigeon pea residue, $\mathrm{N}$ in Brachiaria biomass that was desiccated prior to planting a new summer crop, and $\mathrm{N}$ in maize, sorghum and soybean crop residues.

\subsection{Product output and land requirement from three beef cattle- production systems}

Beef cattle LWG produced over the 10-yr period was lowest in the DP system with only $433 \mathrm{~kg} \mathrm{ha}^{-1}$ due to the lower stocking rate ( 0.5 animals $\mathrm{ha}^{-1} \mathrm{yr}^{-1}$ ) and the lowest number of fattening cycles (3.3 cycles over 10 -yr period) completed (Table 1 ). This low productivity of LWG produced per unit land area is typical for average cattle farms/ranches that practice extensive beef-production systems in Brazil (Landers, 2007), which are still being used in approximately $90 \%$ of pasture areas in Brazil (ANUALPEC, 2010).

In contrast, beef cattle LWG produced in the MP system increased to approximately $9000 \mathrm{~kg} \mathrm{ha}^{-1}$ over the $10-\mathrm{yr}$ period, or more than 20 times higher than the beef cattle LWG output in the DP system over the same period. This high productivity was possible due to better pasture-management practices (i.e., a regular application of balanced fertilizer and liming), resulting in high pasture productivity, and the use of feed supplements to animals, leading to a higher stocking rate and an increased number of fattening cycles completed (5 cycles over 10-yr period; Table 1). Beef cattle LWG produced in the CLFIS was approximately $50 \%$ lower than that under MP system due to the delayed introduction of cattle in this system (as the first 2.5 years was allocated for crop rotations) and a slightly lower stocking rate (3.4 animals ha ${ }^{-1}$; Table 1). However, beef cattle productivity in CLFIS was 10 times higher than that under DP system due to similar improved pasturemanagement practices as in MP.
The agricultural land requirement for producing one $\mathrm{kg}$ of beef cattle live weight (land occupation factor over a 10-year period) was $230 \mathrm{~m}^{2} \mathrm{~kg}^{-1}$ LWG in DP, $22.9 \mathrm{~m}^{2} \mathrm{~kg}^{-1}$ LWG in CLFIS, and $11 \mathrm{~m}^{2} \mathrm{~kg}^{-1}$ LWG in MP, indicating considerable land-saving potential in the MP and CLFIS compared with using the traditional beef cattle production in the DP scenario (Table 1). Although the land occupation value was higher in the CLFIS than in MP, it is important to highlight that the CLFIS has the potential to produce, in addition to beef cattle, three types of grains (maize, sorghum, and soybean, totaling approximately $24.2 \mathrm{Mg} \mathrm{ha}^{-1}$ ) and Eucalyptus timber $\left(26 \mathrm{~m}^{3}\right)$ over the 10 -yr production cycle within the same unit of land area. The MP system produced only one product output, i.e., beef cattle (Table 1 ).

\subsection{Overall GHG balance and carbon footprint}

In calculating the $\mathrm{C}$ footprint of beef cattle, taking into account only the boundary of fattening-cycle farms, emissions were normalized in terms of $\mathrm{kg} \mathrm{CO}_{2} \mathrm{eq}$ per $\mathrm{kg}$ of live weight (LW), which is the weight of the animal at the farm gate, including all parts of the animal that have other potential uses (Desjardins et al., 2012). Our results indicated that the highest $C$ footprint of beef cattle was in DP, which was $18.5 \mathrm{~kg} \mathrm{CO}_{2} \mathrm{eq} \mathrm{kg}^{-1} \mathrm{LW}$, followed by $12.6 \mathrm{~kg} \mathrm{CO}_{2} \mathrm{eq}$ $\mathrm{kg}^{-1} \mathrm{LW}$ in CLFIS, and $9.4 \mathrm{~kg} \mathrm{CO}_{2} \mathrm{eq} \mathrm{kg}^{-1} \mathrm{LW}$ in MP (Table 3). These C footprints are related only to the emissions associated with farm inputs and different farm activities and do not take into account of the technical potential for $C$ sequestration to offset related emissions in MP (soil C) and CLFIS scenarios (soil and Eucalyptus C).

In well-managed pastures in Brazil, a majority of studies have demonstrated increases in soil C stocks (Moraes et al., 1996; Neill et al., 1997; Cerri et al., 2003; Bustamante et al., 2006; Maia et al., 2009; Carvalho et al., 2014), although few studies have shown a depletion of soil $\mathrm{C}$ stocks in newly converted areas from native vegetation (Fearnside and Barbosa, 1998; Hughes et al., 2000; Carvalho et al., 2014). Following Carvalho et al. (2010), we accounted a modest $\mathrm{C}$ sequestration rate of $0.44 \mathrm{Mg} \mathrm{C} \mathrm{ha}^{-1} \mathrm{yr}^{-1}$ for the MP system in this study, while a similar rate of $\mathrm{C}$ accumulation rate was reported by Salton et al. (2014) for an integrated croplivestock system after 10 years of adoption. This management plan can therefore be considered as a strategy to offset GHG emissions from beef cattle production in the MP scenario, especially when recuperating degraded pasture, which would lead to a reduction of the $\mathrm{C}$ footprint of beef cattle fattening from 9.4 to $7.6 \mathrm{~kg} \mathrm{CO} 2$ eq per $\mathrm{kg} \mathrm{LW}$ (Table 3). Considering that CLFIS has capacity to sequester soil $\mathrm{C}$ at a similar rate to that under croplivestock systems reported by Salton et al. (2014), our analysis points to a technical potential of $16,133 \mathrm{~kg} \mathrm{CO}_{2} \mathrm{ha}^{-1}$ that would be accumulated into the soil over a 10-yr cycle (Fig. 3 and Table 3 ).

A recent study has indicated that conversion of conventional agriculture to crop pasture-rotations has capacity to increase soil $\mathrm{C}$ stocks at a rate of $0.733 \mathrm{MgC} \mathrm{ha}{ }^{-1} \mathrm{yr}^{-1}$ within the $0-30 \mathrm{~cm}$ soil depth (Carvalho et al., 2014). However, the duration of soil C accumulation is finite, and the rate of $\mathrm{C}$ accumulation can also differ substantially (West and Six, 2007), resulting in differences in total soil $C$ accumulation capacity between management strategies. Furthermore, it is worth noting that $B$. brizantha has the highest root dry weight at a depth of 50-85 cm (Guenni et al., 2002); hence, the potential for soil $\mathrm{C}$ accumulation in well-managed Brachiaria pasture should take into account of a soil depth from the 0to- $100 \mathrm{~cm}$, for an accurate assessment of $\mathrm{C}$ sequestration potential under these conditions.

There are few case studies that indicated the $C$ sequestration potential of Eucalyptus trees in CLFIS in Brazil (e.g., Ofugi et al., 2008; as cited by Euclides et al., 2010; Tsukamoto Filho, 2003; Pacheco et al., 2012). From these case studies, it is evident that 
Eucalyptus based CLFIS have capacity to sequester between 5.0 and $5.3 \mathrm{Mg} \mathrm{C} \mathrm{ha}^{-1} \mathrm{yr}^{-1}$ (e.g., 18,000 to $19,400 \mathrm{~kg} \mathrm{CO}_{2} \mathrm{ha}^{-1} \mathrm{yr}^{-1}$ ) in the timber component at various tree planting configurations with 250-350 trees ha ${ }^{-1}$ over a $10-y r$ production cycle. When the $\mathrm{C}$ sequestration potential of Eucalyptus timber is taken into consideration as long-lived pool in fences, roofs and corrals, normally used in Brazilian cattle farms, and as utility poles or even for renewable energy generation, the GHG balance from cattle production in CLFIS could be reduced substantially, despite the fact that the net effect of biomass for energy generation could depend on the crop type, the technology for converting biomass into useable energy, and the difference in C stocks between the biomass crop and the pre-existing vegetation (Field et al., 2008).

Based on the average timber yield from Pacheco et al. (2012), which is $26 \mathrm{~m}^{3} \mathrm{ha}^{-1}$ (Table 1 ), we would have approximately $170,000 \mathrm{~kg} \mathrm{CO}_{2} \mathrm{ha}^{-1}$ sequestered in CLFIS in 10 years (Fig. 3 and Table 3 ). Considering the $\mathrm{C}$ sequestration potential from timber in addition to $16,133 \mathrm{~kg} \mathrm{CO}$ from soil $\mathrm{C}$ accumulation (due to NT practices), our results show significant potential to offset GHG emissions from beef cattle fattening under CLFIS, reducing the $C$ footprint to $-28.1 \mathrm{~kg} \mathrm{CO}$ eq per $\mathrm{kg} \mathrm{LW}$ over a 10 -yr cycle (Table 3 ). Moreover, Pacheco et al. (2012) demonstrated that integrated croplivestock-forestry systems in Brazil are economically and technically feasible and provide other important environmental benefits, including long-term ground cover, $\mathrm{C}$ fixation, increase in soil organic matter content, reduction of GHG emissions, improvement in water quality and other ecosystem services (Franzluebbers et al., 2014).

In performing our estimations, we have considered Eucalyptus urograndis to be introduced in a configuration of $14 \times 1.5 \mathrm{~m}$ or 476 trees ha ${ }^{-1}$ and harvested after a $10-y r$ cycle, based on economic performance and their high potential as a C sink (CLFIS scenario). Different crop cycles or Eucalyptus harvest cycles could be used and tested on CLFIS as well as other tree species and spatial arrangements. Therefore, further research should be conducted to better comprehend the interactions among cattle, tree species, grain crops and pasture, the influence of shading, competition for water, nutrients and allelopathy under this promising integrated system.

Improved farming practices usually lead to an increase in yield, resulting in fewer GHG emissions per unit product (Dick et al., 2015). In many cropping systems, balanced fertilization is one of the key factors that controls biomass production and thus may influence patterns of SOC storage (Zanatta et al., 2007). Although, this may lead to higher area-scaled GHG emissions resulting from external input use (e.g., $\mathrm{N}$ fertilizer), improved productivity per unit area leads to lower GHG emissions per unit of product, as indicated in our study. Capper (2011) also showed that improved productivity in the US beef industry has resulted in reductions of GHG emissions per unit product. In these production systems, no-till and reduced soil tillage have received increased attention for their potential to reduce the fuel consumed in crop production (Hernánz et al., 1995; Sijtsma et al., 1998).

Due to the differences in assumptions between different studies, a direct comparison of our results with other studies is challenging. Nevertheless, Desjardins et al. (2012) presented the $C$ footprints for beef cattle $\left(\mathrm{kg} \mathrm{CO}_{2} \mathrm{eq} \mathrm{kg}^{-1} \mathrm{LW}\right)$ calculated from different studies, management practices and spatial scales for Sweden (11.6), France (14.3-18.3), the United Kingdom (8.7-10.4), Canada (8.4-15.3), the United States (13-19.2), the European Union (10.4-13.3), Australia (7.9-12.7) and Brazil (14.3-22.4). Those authors highlighted the fact that the magnitude of the $C$ footprint associated with the production of any product varies depending on the extent or boundary of the selected system, which defines the upstream and downstream processes that are included in the assessment. Here, for more accurate results, we suggest farm boundaries that separate cattle-fattening farms from farms that only produce calves, as is normally observed in Brazil.

For Canada, Desjardins et al. (2012) did not take into account the effect of land-use change (e.g., deforestation from the conversion to agriculture or pasture) on the assertion that conversion of newly deforested lands to beef production is not occurring in Canada, but included increases in soil $\mathrm{C}$ from changes in land management practices, such as increases in no-till land in western Canada (Vergé et al., 2008) when the estimates were revised. For the U.S., the same authors considered combined improvements in management, defined as the slaughter weight of beef cattle, which increased from 274 to $351 \mathrm{~kg}$; the time required to reach slaughter weight decreased from 602 to 482 days. They did not consider the effect of land-use change on soil C. In Australia, one of the largest beef exporters in the world, Ridoutt et al. (2011) calculated the C footprints for six beef cattle-production systems grazing on improved pastures and feedlot finished. They ranged from 10.1 to $12.7 \mathrm{~kg} \mathrm{CO}_{2} \mathrm{eq}$ $\mathrm{kg}^{-1} \mathrm{LW}$ and took into account of emissions from enteric fermentation, $\mathrm{CH}_{4}$ and $\mathrm{N}_{2} \mathrm{O}$ emissions from manure, and emissions associated with inputs such as fuels, fertilizers and supplementary feeds. Land-use change (deforestation) and possible changes in soil $C$ were ignored due to a lack of data.

The results and scope of GHG emissions from beef production in Sweden, as described by Cederberg and Stadig (2003) and explained by Desjardins et al. (2012), considered the milk system to be the core system rather than beef production. However, culled cows and surplus calves are used to produce meat, so the authors considered the beef-production system to be the background system. In addition, Cederberg and Stadig (2003) did not include emissions related to the allocation and expansion of the milk system in Sweden or the emissions from land-use change (LUC) ascribed to the use of imported feed. Here, we emphasize that studies that attempt to estimate the $C$ footprint from cattle should describe the details of their production systems and distinguish their emission sources, production factors, emission factors and boundaries to be comparable. Using a comparative life cycle assessment (LCA) approach, Ruviaro et al. (2015) presented the $C$ footprint in different beef production systems on a southern Brazilian farm of $18.3 \mathrm{~kg} \mathrm{CO}_{2} \mathrm{eq} \mathrm{kg}^{-1} \mathrm{LW}$ for the ryegrass and sorghum

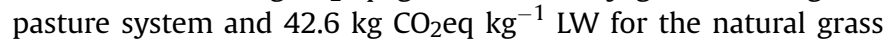
system, including the contributions of cows, calves and steers.

It is generally regarded that continued growth of ruminant meat consumption will represent a major obstacle for reaching ambitious climate-change targets (Ripple et al., 2014); however, reducing the consumption of food from ruminant production systems will be a difficult and complex task. Average meat consumption has increased significantly, from $30.7 \mathrm{~kg} \mathrm{yr}^{-1}$ in the mid-1980s to $36.4 \mathrm{~kg} \mathrm{yr}^{-1}$ at present, and it is projected to increase to $41.3 \mathrm{~kg} \mathrm{yr}^{-1}$ in 2015 (FAO, 2014). In our study, we showed that by improving the management of pasture systems, it is possible to reduce the $C$ footprint from beef cattle as a result of a better efficiency in LW gain in time and space. The potential for $C$ sequestration in soil and by Eucalyptus trees means that the adoption of CLFIS could be a feasible strategy to offset cattle emissions or even serve as a net sink for atmospheric $\mathrm{CO}_{2}$. In addition to improved cattle productivity, deforestation to establish new pastures could be avoided, and extra income could come from Eucalyptus and crops used as feed supplement for animals, with CLFIS becoming a cleaner production system.

\section{Conclusions}

Although the DP scenario presented the lowest total emissions per unit land area, it is not possible to reduce the $C$ footprint of cattle production in this system, which occupies large areas with 
low yield and high GHG emissions per kg of product compared with more intensive production systems, such as MP and CLFIS.

The conversion of degraded pasture to well-managed pasture and the introduction of CLFIS can reduce their associated GHG emissions in terms of $\mathrm{kg} \mathrm{CO} 2 \mathrm{eq}$ emitted per $\mathrm{kg}$ of cattle LW produced, increasing meat, grains and timber production. This reduction is due primarily to pasture improvement and increases in cattle yields and the realization of technical potential for $\mathrm{C}$ sinks in soil and in biomass to offset cattle-related emissions.

The intensification of cattle-production systems can contribute to avoiding further deforestation as a result of lower landoccupation factors in these systems. Additional efforts should be made to achieve a better comprehension of more intensive pasturemanagement systems, such as MP and CLFIS, their interactions with associated GHG emissions and their potential for C uptake in biomass and soil. Such research could result in supplementary knowledge and strategies to reduce GHG emissions from cattle production, contributing to mitigating climate change and promoting food security.

\section{Acknowledgments}

We are grateful to Fundação de Amparo à Pesquisa do Estado de São Paulo (FAPESP; grants 11/00060-8 and 12/14907-5), Conselho Nacional de Desenvolvimento Científico e Tecnológico (CNPq) and Coordenação de Aperfeiçoamento de Pessoal de Nível Superior (CAPES) for financial support.

\section{References}

ANUALPEC, 2010. Anuário da Pecuária Brasileira. FNP Consultoria \& Comércio, São Paulo.

Balbino, L.C., Cordeiro, A.M.C., de Oliveira, P., et al., 2012. Agricultura sustentável por meio da Integração Lavoura-Pecuária-Floresta (iLPF). Informações Agronômicas. International Plant Nutrition Institute (IPNI). Available at: http://www.ipni.net PUBLICATION/IA-BRASIL.NSF/0/37D541B90CDB2E1685257A84005C6490/\$FILE Jornal1-18-138.pdf (accessed 23.04.14.).

Balieiro Neto, G., Reis, R.A., Ruggieri, A.C., 2009a. Impacts of limestone and nitrogen top dressing application on the potassium content in the soil profile and marandu-grass leaf concentration. Rev. Bras. Zootecn. 38 (7), 1170-1175. http:// dx.doi.org/10.1590/S1516-35982009000700002.

Balieiro Neto, G. Berndt, A., Nogueira, J.R., Demarchi, JJ.A., Nogueira Filho, J.C.M 2009b. Monensin and protein supplements on methane production and rumen protozoa in bovine fed low quality forage. South African J. Anim. Sci. 39, 280-283.

Barretto, A.G.O.P., Goran, B., Sparovek, G., Wirsenius, S., 2013. Agricultural intensification in Brazil and its effects on land-use patterns: an analysis of the 1975-2006 period. Glob. Change Biol. 19, 1804-1815. http://dx.doi.org/10.1111/ gcb.12174.

Berchielli, T.T., Fiorentini, G., Carvalho, I.P.C., Berndt, A., Frighetto, R.T.S., Canesin, R.C., Lage, J.F., 2011. Effects of lipid sources in steers performance and methane emission finished in feedlot. Adv. Anim. Biosci. 2 (2), 405-570. http:/ dx.doi.org/10.1017/S2040470011002809. Published online by Cambridge University Press 11 Aug 2011.

Berndt, A., Tomkins, N.W., 2013. Measurement and mitigation of methane emissions from beef cattle in tropical grazing systems: a perspective from Australia and Brazil. Animal 7 (s2), 363-372. http://dx.doi.org/10.1017/ S1751731113000670.

Boddey, R.M., Macedo, R., Tarré, R.M., et al., 2004. Nitrogen cycling in Brachiaria pastures: the key to understanding the process of pasture decline? Agric. Ecosyst. Environ. 103, 389-403. http://dx.doi.org/10.1016/j.agee.2003.12.010.

Braz, S.P., Urquiaga, S., Alves Jr., B., Jantalia, C., Guimarães, A.P.P., dos Santos, C.A., dos Santos, S.C., Boddey, R.M., 2013. Soil carbon stocks under productive and degraded pastures in the Brazilian cerrado. Soil Sci. Soc. Am. J. 77, 914-928. http://dx.doi.org/10.2136/sssaj2012.0269.

Brazil, 2012. Plano ABC (Agricultura de Baixa Emissão de Carbono). Ministério da Agricultura, Pecuária e Abastecimento, Ministério do Desenvolvimento Agrário - MAPA/ACS, Brasília/DF, p. 173. ISBN 978-85-7991-062-0. Available at: http:// www.agricultura.gov.br/arq_editor/download.pdf (accessed 18.05.15.).

Bustamante, M.M.C., Corbeels, M. Scopel, E., Roscoe, R., 2006. Soil carbon and sequestration potential in the Cerrado Region of Brazil. In: Lal, R., Cerri, C.C., Bernoux, M., Etchevers, J., Cerri, C.E.P. (Eds.), Carbon Sequestration in Soils of Latin America. Haworth, New York, pp. 285-304. ISBN 978-1-56022-137-1.
Bustamante, M.M.C., Nobre, C.A., Smeraldi, R., et al., 2012. Estimating greenhouse gas emissions from cattle raising in Brazil. Clim. Change 115 (3-4), 559-577. http://dx.doi.org/10.1007/s10584-012-0443-3.

Capper, J.L., 2011. Replacing rose-tinted spectacles with a high-powered microscope: the historical versus modern carbon footprint of animal agriculture. Anim. Front. 1 (1), 26-32. http://dx.doi.org/10.2527/af.2011-0009.

Carvalho, J.L.N., Raucci, G.S., Cerri, C.E.P., Bernoux, M., Feigl, B.J., Wruck, F.J., Cerri, C.C., 2010. Impact of pasture, agriculture and crop-livestock systems on soil C stocks in Brazil. Soil Till. Res. 110, 175-186. http://dx.doi.org/10.1016/ j.still.2010.07.011.

Carvalho, J.L.N., Raucci, G.S., Frazão, L.A., Cerri, C.E.P., Bernoux, M., Cerri, C.C., 2014. Crop-pasture rotation: a strategy to reduce soil greenhouse gas emissions in the Brazilian Cerrado. Agric. Ecosyst. Environ. 183, 167-175. http://dx.doi.org/ 10.1016/j.agee.2013.11.014.

Casagrande, D.R., Ruggieri, A.C., Moretti, M.H., Berchielli, T.T., Vieira, B.R., Roth, A.P.T.P., Reis, R.A., 2011. Sward canopy structure and performance of beef heifers under supplementation in Brachiaria brizantha cv. Marandu pastures maintained with three grazing intensities in a continuous stocking system. Rev. Bras. Zootecn 40 (10), 2074-2082. http://dx.doi.org/10.1590/S151635982011001000002 .

Cederberg, C., Stadig, M., 2003. System expansion and allocation in life cycle assessment of milk and beef production. Int. J. Life Cycl. Assess. 8, 350-356. http://dx.doi.org/10.1007/BF02978508.

Cerri, C.E.P., Coleman, K., Jenkinson, D.S., Bernoux, M., Victoria, R.L., Cerri, C.C., 2003. Modeling soil carbon from forest and pasture ecosystems of Amazon. Brazil. Soil Sci. Soc. Am. J. 67, 1879-1887. http://dx.doi.org/10.2136/sssaj2003.1879.

Cerri, C.E.P., Bernoux, M., Chaplot, V., Volkoff, B., Victoria, R.L., Melillo, J.M., Paustian, K., Cerri, C.C., 2004. Assessment of soil property spatial variation in an Amazon pasture: basis for selecting an agronomic experimental area. Geoderma 123, 51-68. http://dx.doi.org/10.1016/j.geoderma.2004.01.027.

Cerri, C.E.P., Sparovek, G., Bernoux, M., Easterling, W.E., Melillo, J.M., Cerri, C.C., 2007. Tropical agriculture and global warming: impacts and mitigations options. Sci. Agric. 64, 83-99. http://dx.doi.org/10.1590/S010390162007000100013.

Cerri, C.C., Maia, S.M.F., Galdos, M.V., Cerri, C.E.P., Feigl, B.J., Bernoux, M., 2009. Brazilian greenhouse gas emissions: the importance of agriculture and livestock. Sci. Agric. 66, 831-843. http://dx.doi.org/10.1590/S0103-90162009000600017.

CETESB, 2011. Companhia Ambiental do Estado de São Paulo. Available at: http:// www.cetesb.sp.gov.br/ar/documentos/Relatorio_de_Emissoes_Veiculares_no_ Estado_de_Sao_Paulo_2011.pdf (accessed 10.07.14.).

Corazza, EJ. Silva, J.E. Resk, D.V.S., Gomes, A.C. 1999. Behavior of different management systems as a source or sink of $\mathrm{C}_{-} \mathrm{CO}_{2}$ in relation to cerrado type vegetation. Rev. Bras. Cienc. Solo 23, 425-432.

Corsi, M., Martha Jr., G.B., Nascimento Jr., D., Balsalobre, M.A., 2001. Impact of grazing management on productivity of tropical grasslands. In: XIX International Grassland Congress, Proceedings. São Pedro, Brazil, pp. 801-805.

De Figueiredo, E.B., La Scala Jr., N., 2011. Greenhouse gas balance due to the conversion of sugarcane areas from burned to green harvest in Brazil. Agric. Ecosyst. Environ. 141, 77-85. http://dx.doi.org/10.1016/j.agee.2011.02.014.

De Oliveira, O.C., de Oliveira, I.P., Ferreira, E., Alves, B.J.R., Miranda, C.H.B., Vilela, L., Urquiaga, S., Boddey, R.M., 2001. Response of degraded pastures in the Brazilian cerrado to chemical fertilization. Past. Tropic 23 (1), 14-18.

De Oliveira, S.G., Berchielli, T.T., Pedreira, M.D., Primavesi, O., Frighetto, R., Lima, M.A., 2007. Effect of tannin levels in sorghum silage and concentrate supplementation on apparent digestibility and methane emission in beef cattle. Anim. Feed Sci. Tech. 135, 236-248.

Demarchi, J.J.A.A., Manella, M.Q., Lourenço, A.J., Alleoni, G.F., Frighetto, R.T.S., Primavesi, O., Lima, M.A., 2003. Preliminary results on methane emission by Nelore cattle in Brazil grazing Brachiaria brizantha cv. Marandu. In: International Methane \& Nitrous Oxide Mitigation Conference, Proceedings. China Coal Information Institute, Beijing, pp. 80-82.

Desjardins, R.L., Worth, D.E., Vergé, X.P.C., Maxime, D., Dyer, J., Cerkow, D., 2012. Carbon footprint of beef cattle. Sustainability 4, 3279-3301. http://dx.doi.org/ $10.3390 /$ su4123279.

Detmann, E., Paulino, M.F., Zervoudakis, J.T., Cecon, P.R., Valadares Filho, S.C., Gonçalves, L.C., Cabral, L.S., Melo, A.J.N.M., 2004. Níveis de Proteína Bruta em Suplementos Múltiplos para Terminação de Novilhos Mestiços em Pastejo Durante a Época Seca: desempenho Produtivo e Características de Carcaça. Rev. Bras. Zootecn. 33 (1), 169-180.

Dick, M., Da Silva, M.A., Dewes, H., 2015. Mitigation of environmental impacts of beef cattle production in southern Brazil - evaluation using farm-based life cycle assessment. J. Clean. Prod. 87, 58-67. http://dx.doi.org/10.1016/ j.jclepro.2014.10.087

Don, A., Schumacher, J., Freibauer, A., 2011. Impact of tropical land-use change on soil organic carbon stocks - a meta-analysis. Glob. Change Biol. 17, 1658-1670. http://dx.doi.org/10.1111/j.1365-2486.2010.02336.x.

Dube, F., Couto, L., Silva, M.L., Leite, H.G., García, R., Araújo, G.A.A., 2002. A simulation model for evaluating technical and economic aspects of an industrial eucalyptus-based agroforestry system in Minas Gerais, Brazil. Agrofor. Syst. 55 (1), 73-80.

Eckard, R.J., Grainger, C., de Klein, C.A.M., 2010. Options for the abatement of methane and nitrous oxide from ruminant production: a review. Livest. Sci. 130, 47-56. http://dx.doi.org/10.1016/j.livsci.2010.02.010.

Embrapa, 2006. Empresa Brasileira de Pesquisa Agropecuária. Adubação nitrogenada para pastagens do gênero Brachiaria em solos do Cerrado/Kátia 
Aparecida de Pinho Costa, Itamar Pereira de Oliveira, Valdemar Faquin. Embrapa Arroz Feijão St. Antônio Goiás, Doc. 192, 60 p. ISSN 1678-9644.

Embrapa, 2007. Empresa Brasileira de Pesquisa Agropecuária. Marandu: cultivar de Brachiaria brizantha. Embrapa Gado de Corte, Campo Grande, p. 2. Available at: http://www.cnpgc.embrapa.br/produtoseservicos/pdf/marandu.pdf (accessed 12.05.12.).

Euclides, V.P.B., Euclides Filho, K., Arruda, Z.J., et al., 1998. Desempenho de novilhos em pastagens de Brachiaria decumbens submetidos a diferentes regimes alimentares. Rev. Bras. Zootecn. 27 (2), 246-254.

Euclides, V.P.B., Euclides Filho, K., Costa, F.P., Figueiredo, G.R.D., 2001. Desempenho de novilhos F1s Angus-Nelore em pastagens de Brachiaria decumbens submetidos a diferentes regimes alimentares. Rev. Bras. Zootecn. 30 (2), 470-481.

Euclides, V.P.B., do Valle, C.B., Macedo, M.C.M., Almeida, R.G.D., Montagner, D.B., Barbosa, R.A., 2010. Brazilian scientific progress in pasture research during the first decade of XXI century. Rev. Bras. Zootecn. 39, 151-168.

FAO, 2014. Food and Agriculture Organization of the United Nations. Available at: http://www.fao.org/docrep/005/y4252e/y4252e05b.htm (accessed 10.03.14.).

Fearnside, P.M., Barbosa, R.I., 1998. Soil carbon changes from conversion of forest to pasture in Brazilian Amazon. Forest Ecol. Manag. 108, 147-166. http:// dx.doi.org/10.1016/S0378-1127(98)00222-9.

Fernandes, L.O., Reis, R.A., Paes, J.M.V., 2010. Efeito da suplementação no desempenho de bovinos de corte em pastagem de Brachiaria brizantha cv. Marandu. Ciênc. Agrotec. 34, 240-248.

Ferraz, J.B., Felicio, P.E., 2010. Production systems-an example from Brazil. Meat Sci. $84,238-243$.

Field, C.B., Campbell, J.E., Lobell, D.B., 2008. Biomass energy: the scale of the potential resource. Trends Ecol. Evol. 23 (2), 65-72.

Franzluebbers, A.J., Lemaire, G., de Faccio, P.C., Sulc, R.M., Dedieu, B., 2014. Toward agricultural sustainability through integrated crop-livestock systems: environmental outcomes. Agric. Ecosyst. Environ. 190, 1-3.

García-Préchac, F., Ernst, O., Siri-Prieto, G., Terra, J.A., 2004. Integrating no-till into crop-pasture rotations in Uruguay. Soil Till. Res. 77, 1-13. http://dx.doi.org/ 10.1016/j.still.2003.12.002.

Gil, J., Siebold, M., Berger, T., 2015. Adoption and development of integrated crop-livestock-forestry systems in Mato Grosso, Brazil. Agric. Ecosyst. Environ. 199, 394-406.

Gominho, J., Figueira, J., Rodrigues, J.C., Pereira, H., 2001. Within-tree variation of heartwood, extractives and wood density in the eucalypt hybrid urograndis (Eucalyptus grandis $\times$ E. urophylla). Wood Fiber Sci. 33 (1), 3-8.

Guenni, O., Marín, D., Baruch, Z., 2002. Responses to drought of five Brachiaria species. I. Biomass production, leaf growth, root distribution, water use and forage quality. Plant Soil 243 (2), 229-241.

Hernánz, J.L., Girón, V.S., Cerisola, C., 1995. Long-term energy use and economic evaluation of three tillage systems for cereal and legume production in central Spain. Soil Till. Res. 35, 183-198. http://dx.doi.org/10.1016/0167-1987(95) 00490-4.

Hughes, R.F., Kauffman, J.B., Cummings, D.L., 2000. Fire in the Brazilian Amazon. 3. Dynamics of biomass, $\mathrm{C}$, and nutrient pools in regenerating forests. Oecologia $124,574-588$.

IBGE, 2013. Instituto Brasileiro de Geografia e Estatística, 40. Produção da Pecuária Municipal, Rio de Janeiro, p. 71, 2012. ISSN 0101-4234. Available at: ftp://ftp. ibge.gov.br/Producao_Pecuaria/Producao_da_Pecuaria_Municipal/2012/ ppm2012.pdf (accessed 22.09.13.)

IPCC, 2006. Guidelines for National Greenhouse Gas Inventories. In: Eggleston, S. Buendia, L., Miwa, K., Ngara, T., Tanabe, K. (Eds.), IPCC National Greenhouse Gas Inventories Programme. Institute for Global Environmental Strategies (IGES), Hayama, Japan, p. 664.

IPCC, 2007. Climate change 2007: the physical science basis. In: Solomon, S., Qin, D. Manning, M., Marquis, M., Averyt, K., Tignor, M.M.B., et al. (Eds.), Contribution of Working Group I to the Fourth Assessment Report of the Intergovernmental Panel on Climate Change. Cambridge University Press, Cambridge, United Kingdom and New York, NY, USA, p. 996.

IPCC, Intergovernmental Panel on Climate Change, Ciais, P., Sabine, C., Bala, G., Bopp, L., Brovkin, V., Canadell, J., Chhabra, A., DeFries, R., Galloway, J., Heimann, M., Jones, C., Le Quéré, C., Myneni, R.B., Piao, S., Thornton, P., 2013. Carbon and other biogeochemical cycles. In: Climate Change 2013: the Physical Science Basis. Cambridge University Press, Cambridge, United Kingdom and New York, NY, USA.

IPCC, 2014. Intergovernmental panel on climate change. In: Smith, P., Bustamante, M. (Eds.), Working Group III Contribution to the IPCC 5th Assessment Report "Climate Change 2014: Mitigation of Climate Change" that was Accepted but Not Approved in Detail by the 12th Session of Working Group III and the 39th Session of the IPCC on April 122014 in Berlin, Germany.

La Scala Jr., N., De Figueiredo, E.B., Panosso, A.R., 2012. A review on soil carbon accumulation due to the management change of major Brazilian agricultural activities. Braz. J. Biol. 72 (3), 775-785. http://dx.doi.org/10.1590/S151969842012000400012 .

Landers, J.N., 2007. Tropical Crop-livestock Systems in Conservation Agriculture: the Brazilian Experience. Food and Agriculture Organization of the United Nations. Book Chapter. Rome. Integrated Crop Management, vol. 5.

Lessa, A.C.R., Madari, B.E., Paredes, D.S., Boddey, R.M., Urquiaga, S., Jantalia, C.P., Alves, B.J., 2014. Bovine urine and dung deposited on Brazilian savannah pastures contribute differently to direct and indirect soil nitrous oxide emissions. Agric. Ecosyst. Environ. 190, 104-111.
Lilienfein, J., Wilcke, W., Vilela, L., Ayarza, M.A., Lima, S.C., Zech, W., 2003. Soil fertility under native Cerrado and pasture in the Brazilian savanna. Soil Sci. Soc. Am. J. 67, 1195-1205.

Macedo, M.C.M., 1995. Pastagens no ecossistema cerrados. In: Simpósio Sobre Pastagens Nos Ecossistemas Brasileiros: pesquisas para o desenvolvimento sustentável. SBZ, Brasília. Anais... Brasília, pp. 28-62.

Macedo, M.C.M., 2004. Análise comparativa de recomendações de adubação em pastagens. In: Simpósio Sobre Manejo Da Pastagem, 21., Piracicaba. FEALQ Anais... Piracicaba, pp. 317-355.

Macedo, M.C.M., 2005. Pastagens no ecossistema cerrados: evolução das pesquisas para o desenvolvimento sustentáveis. In: Reunião Anual Da Sociedade Brasileira De Zootecnia, 42., Goiânia. SBZ, Anais... Goiânia, pp. 56-84.

Macedo, I.C., Leal, M.L.R.V., Silva, J.E.A.R., 2004. Balanço das emissões de gases de efeito estufa na produção e no uso do ethanol no Brasil. UNICA, São Paulo/SP. Available at: http://www.unica.com.br/download.php?idSecao=17\&id=11168105 (accessed 25.04.14.).

Macedo, I.C., Seabra, J.E.A., Silva, J.E.A.R., 2008. Greenhouse gases emissions in the production and use of ethanol from sugarcane in Brazil: the 2005/2006 averages and a prediction for 2020. Biomass Bioenergy 32, 582-595. http:// dx.doi.org/10.1016/j.biombioe.2007.12.006.

Maia, S., Ogle, S., Cerri, C.C., 2009. Effect of grassland management on soil carbon sequestration in Rondonia and Mato Grosso states, Brazil. Geoderma 149, 84-89. http://dx.doi.org/10.1016/j.geoderma.2008.11.023.

Mandarino, R.A., Pereira, L.G.R., Barbosa, F.A., Santos, D.C., Vilela, L., Maciel, G.D.A. Júnior, R.G., 2014. Methane emissions from Nellore heifers under integrated crop livestock forest systems. In: Embrapa Informática Agropecuária - Resumos em anais de congresso (ALICE). Livestock, Climate Change and Food Security Conference, Madrid. Conference abstract book...[Paris]: INRA.

Marchão, R.L., Balbino, L.C., Silva, E.M., Santos, J.D.G., Sá, M.A.C., Vilela, L., Becquer, T. 2007. Soil physical quality under crop-livestock management systems in a Cerrado Oxisol. Pesq. Agrop. Bras. 42, 873-882. http://dx.doi.org/10.1590/ S0100-204X2007000600015.

Marchão, R.L., Becquer, T., Didier, B.D., Balbino, L.C., Vilela, L., Brossard, M., 2009. Carbon and nitrogen stocks in a Brazilian clayey Oxisol: 13-year effects of integrated crop-livestock management systems. Soil Till. Res. 103, 442-450. http://dx.doi.org/10.1016/j.still.2008.11.002.

Millen, D.D., Arrigoni, M.D.B., 2013. Drivers of change in animal protein production systems: changes from 'traditional' to 'modern' beef cattle production systems in Brazil. Anim. Front. 3 (3), 56-60. http://dx.doi.org/10.2527/af.2013-0025.

Monteiro, F.A., Colozza, M.T., Werner, J.C., 2004. Enxofre e micronutrientes em pastagens. In: Simpósio Sobre Manejo De Pastagem, 21. Piracicaba. Anais. Piracicaba: FEALQ, pp. 279-301.

Moraes, J.F.L., Volkoff, B., Cerri, C.C., Bernoux, M., 1996. Soil properties under Amazon forest and changes due to pasture installation in Rondônia, Brazil. Geoderma 70, 63-81. http://dx.doi.org/10.1016/0016-7061(95)00072-0.

Neill, C., Melillo, J.M., Steudler, P.A., Cerri, C.C., de Moraes, J.F.L., Piccolo, M.C. Brito, M., 1997. Soil carbon and nitrogen stocks following forest clearing for pasture in the southwestern Brazilian Amazon. Ecol. Appl. 7,1216-1225. http:// dx.doi.org/10.1890/1051-0761(1997)007[1216:SCANSF]2.0.CO;2.

Ofugi, C., Magalhães, L.L., Melido, R.C.N., et al., 2008. Integração lavoura-pecuária (ILPF), sistemas agroflorestais (SAFs). In: TRECENTI, R. (Ed.), Integração Lavourapecuária Silvicultura. MAPA/SDC, Brasília, pp. 20-25.

Oliveira, P.P.A., Boaretto, A.E., Trivelin, P.C.O., de Oliveira, W., Corsi, M., 2003. Liming and fertilization to restore degraded Brachiaria decumbens pastures grown on an entisol. Sci. Agric. 60 (1), 125-131. http://dx.doi.org/10.1590/S010390162003000100019.

Oliveira, A.P., Bertipaglia, L.M.A., de Melo, G.M.P., Berchielli, T.T., Ruggieri, A.C. Casagrande, D.R., Reis, A.R., 2012. Performance of supplemented heifers on Marandu grass pastures in the wet-to-dry transition and dry seasons. Rev. Bras. Zootecn. 41 (10), 2255-2262. http://dx.doi.org/10.1590/S1516-35982012001000017.

Pacheco, A.R., Chaves, R.D.Q., Nicoli, C.M.L., 2012. Integration of crops, livestock, and forestry: a system of production for the Brazilian Cerrados. In: Cassman, K.G. (Ed.), Eco-efficiency: from Vision to Reality. Ch. 4, (CIAT: Cali, Colombia).

Paulino, M.F., Detmann, E., Zervoudakis, J.T., 2001. Suplementos múltiplos para recria e engorda de bovinos em pastejo. In: Simpósio De Produção De Bovinos De Corte, 2. Viçosa. UFV, Anais... Viçosa, pp. 187-232.

Peron, A.J., Evangelista, A.R., 2003. Degradação de pastagens em regiões de cerrado. Ciência Tecnol 28, 655-661.

Peters, G.M., Rowley, H.V., Wiedemann, S., Tucker, R., Short, M., Schulz, M., 2010 Red meat production in Australia-a life cycle assessment and comparison with overseas studies. Environ. Sci. Technol. 44 (4), 1327-1332. http://dx.doi.org/ 10.1021/es901131e.

Reis, R.A., Ruggieri, A.C., Casagrande, D.R., 2009. Suplementação da dieta de bovinos de corte como estratégia do manejo das pastagens. Rev. Bras. Zootecn. 38 $147-159$.

Ridoutt, B.G., Sanguansri, P., Harper, G.S., 2011. Comparing carbon and water footprints for beef cattle production in southern Australia. Sustainability 3, 2443-2455. http://dx.doi.org/10.3390/su3122443.

Ripple, W.J., Smith, P., Haberl, H., Montzka, S.A., McAlpine, C., Boucher, D.H., 2014 Ruminants, climate change and climate policy. Nat. Clim. Chang. 4 (1), 2-5. http://dx.doi.org/10.1038/nclimate2081.

Ruviaro, C.F., De Léis, C.M., Lampert, V.N., Barcellos, J.O.J., Dewes, H., 2015. Carbon footprint in different beef production systems on a southern Brazilian farm: a case study. J. Clean. Prod. 96, 435-443. http://dx.doi.org/10.1016/ j.jclepro.2015.05.107. 
Salmi, G.P., Salmi, A.P., Abboud, A.C.S., 2006. Dinâmica de decomposição e liberação de nutrientes de genótipos de guandu sob cultivo em aléias. Pesq. Agrop. Bras. 41 (4), 673-678.

Salton, J.C., Mielniczuk, J., Bayer, C., Fabrício, A.C., Macedo, M.C.M., Broch, D.L., 2011 Teor e dinâmica do carbono no solo em sistemas de integração lavoura-pecuária. Pesq. Agrop. Bras. 46 (10), 1349-1356.

Salton, J.C., Mercante, F.M., Tomazi, M., Zanatta, J.A., Concenço, G., Silva, W.M., Retore, M., 2014. Integrated crop-livestock system in tropical Brazil: toward a sustainable production system. Agric. Ecosyst. Environ. 190, 70-79.

Sijtsma, C.H., Campbell, A.J., McLaughlin, N.B., Carter, M.R., 1998. Comparative tillage costs for crop rotations utilizing minimum tillage on a farm scale. Soil Till. Res. 49, 223-231. http://dx.doi.org/10.1016/S0167-1987(98)00175-5.

Silva, J.E., Resck, D.V.S., Corazza, E.J., Vivaldi, L., 2004. Carbon storage in clayey Oxisol cultivated pastures in the "Cerrado" region, Brazil. Agri. Ecosyst. Environ. 103, 357-363. http://dx.doi.org/10.1016/j.agee.2003.12.007.

Souza, D.M.G., Lobato, E., 2002. Correção da acidez do solo. In: Cerrado: Correção do solo e adubação. Embrapa Cerrados, Planaltina, pp. 81-96.

Torres, J.L.R., Pereira, M.G., Fabian, A.J., 2008. Produção de fitomassa por plantas de cobertura e mineralização de seus resíduos em plantio direto. Pesq. Agrop. Bras. 43 (3), 421-428.

Tsukamoto Filho, A.A., 2003. Fixação do carbono em um sistema agroflorestal com eucalipto na região do Cerrado em Minas Gerais. PhD thesis. Universidade Federal de Viçosa, Viçosa, p. 98.
UNFCCC, 2007. Views on the Range of Topics and Other Relevant Information Relating to Reducing Emissions from Deforestation in Developing Countries. Submissions from Parties. Available at: http://unfccc.int/resource/docs/2007/ sbsta/eng/misc03.pdf (accessed 21.05.14.).

UNFCCC, 2013. Views on Land Use, Land-use Change and Forestry Issues Referred to in Decision 2/CMP.7, Paragraphs 5-7. Submissions from Parties and Admitted Observer Organizations 12-18 (SBSTA, UNFCCC, 2013). Available at: http://go. nature.com/hLAtTN (accessed 18.12.13.).

Vergé, X.P.C., Dyer, J.A., Desjardins, R.L., Worth, D., 2008. Greenhouse gas emissions from the Canadian beef industry. Agr. Syst. 98, 126-134. http://dx.doi.org/ 10.1016/j.agsy.2008.05.003.

Werner, J.C., Paulino, V.T., Cantarella, H., 1996. Recomendação de adubação e calagem para forrageiras. In: Raij, B. van, Silva, N.M., Bataglia, O.C., Quaggio, J.A., Hiroce, R., Cantarella, H., Bellinazzi Jr., R., Dechen, A.R., Trani, P.E. (Eds.), Recomendação de adubação e calagem para o Estado de São Paulo. Instituto Agronômico; Fundação IAC, Campinas, pp. 263-271.

West, T.O., Six, J., 2007. Considering the influence of sequestration duration and carbon saturation on estimates of soil carbon capacity. Clim. Change 80 (1-2), 25-41.

Zanatta, J.A., Bayer, C., Dieckow, J., Vieira, F.C.B., Mielniczuk, J., 2007. Soil organic carbon accumulation and carbon costs related to tillage, cropping systems and nitrogen fertilization in a subtropical Acrisol. Soil Till. Res. 94, 510-519. http:// dx.doi.org/10.1016/j.still.2006.10.003. 